\author{
日本における土・石積み構法に関する研究（その1）： \\ 広島県三次・世羅周辺の土・石積み壁をもつ灰屋に関する研究 \\ CONSTRUCTION METHOD OF STACKING EARTH AND STONE IN JAPAN (PART 1): \\ "HANYA" WITH EARTH AND STONE MASONRY WALL \\ IN THE VICINITY OF MIYOSHI AND SERA, HIROSHIMA PREFECTURE
}

\author{
中 村 航*1, 山田宮土理*2, 中 村美 貴*3 \\ Wataru NAKAMURA, Midori YAMADA and Miki NAKAMURA
}

\begin{abstract}
A survey was conducted on the ash houses "Hanya"distributed around Miyoshi and Sera, Hiroshima Prefecture. From the literature survey, we extracted and organized information on the origins of Hanya, their names, methods of making and using ashes, their locations, dates of construction, changes in use, and architectural composition. Building materials, construction methods and building construction were analyzed from the actual survey. These results were used to discuss the changes in the use of Hanya and their effects on building materials and construction methods, as well as the standard form of Hanya today.
\end{abstract}

Keywords : Warehouse, Cob construction, Stone masonry, Hanya, Attached Building, Farmhouse 小屋, 土積夕, 石積夕, 灰屋, 付属屋, 農家

\section{1. はじめに}

日本では古くから土が建築に用いられており、堅穴住居には植物 材料を下地とした土莫きの屋根が使用されていたことがわかってい

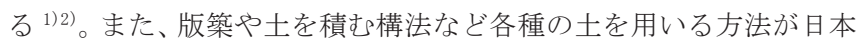
に存在した注1)。しかし、世界的にはよくみられる日干しレンガの組 積造、版築や練った土で直接壁を形成する一体式の壁構造は、日本 では主要な建築構造になることはほとんどなく、突いたり、積んだ り寸る技術は、土塁、古墳などの土木分野、また建築分野では基礎 や塀などを対象に主に用いられている。建築の壁構法としては、躯 体を木造軸組とし、柱間に竹や枝を編んだ下地をつくり、土と葍を 練った壁土を鏝で塗り付けて壁を構成する塗り壁構法が、土の一般 的な利用方法となっている。

一方、土のみ、または土と石を積んで壁をつくる構法（以下、土・ 石積み構法と呼ぶ）を用いた建築が近畿以西の各地に確認されてい る。既往の研究では、兵庫県篠山市の灰屋 ${ }^{4)}$ 、山口県豊浦町の土蔵

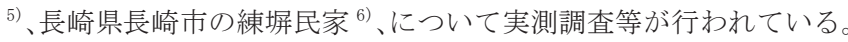
また、筆者らは奈良県の塀・小屋 ${ }^{7)}$ 、大分県国東半島の小屋 ${ }^{899)}$ 10)、 について実測調查を行い、その結果を報告した。土のみの場合もあ るが、長崎や大分など石も一緒に積んでいる地域もある。

これらの建物は、倉、牛・馬屋、灰屋、納屋などの附属屋であり、 今では新しく建てられることは無く、代替わりや耐用年数を迎える
ことで取り壊されていくことが多い。

管見の限りでは、現在版築や日干し煉瓦による壁をもつ建築はほ とんど無いため、土積みおよび土・石積み壁は、塗り壁構法以外に も土で建築をつくる技術が日本にあったことを知る重要な手掛りで ある。また、主屋と比べて更新が遅れやすい附属屋であり、地域の 自然素材を用いているこれらの建築は、風土や当時の暮らしとの関 係性を未だに強く残しており、多雨で地震の多いわが国で土と石を 積む方法を選択し、今日まで残ってきた理由とその工学的な技術解 明を行う上で貴重である。本研究は、土・石積み構法による壁を用 いた建築について、建物の構成やその利用方法について調查を行い、 その建築的特質を明らかにすることを目的とする。

広島県の三次・世羅地方周辺にはFig. 2 に示寸ように、地面から 人の背丈程度まで土や石を積んだ壁(以下、土・石積み壁と呼ぶ)を 有寸る灰屋 (ハンヤ) と呼ばれる小屋が分布している。灰屋とは、か まどや囲炉裏、風呂を炊いた際に出る灰などを農業用の肥料として

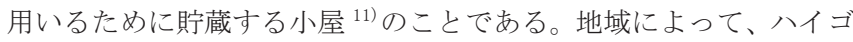
ヤ、ハイナヤなどとも呼ばれ、木造、コンクリート造などつくりに 違いはあるが全国各地にみられる ${ }^{12)}$ 。保管が主な目的である灰屋が 多いなか、広島や兵庫 ${ }^{4)}$ の灰屋は内部で火を焚いて灰をつくり、土・ 石を積んで壁を構成する点も類似している。広島の灰屋は軸組の存 在が明らかで、柱間を埋めるように土・石積み壁が用いられるなど、
奈良女子大学生活環境学部住環境学科 助教·博士 (工学)
早稲田大学理工学術院 准教授・博士 (工学)
奈良女子大学人間文化総合科学研究科 住環境学専攻学士 (生活環境学)
Assist. Prof., Dept. of Architecture, Nara Women's Univ., Dr.Eng. Assoc. Prof., Dept. of Architecture, Waseda Univ., Dr.Eng.

Nara Women's Univ., B. Human Life and Environment 
他の地域の土・石積み壁を有する建築とは異なる構成となっている。 本報は、広島県の三次・世羅地方周辺に分布する灰屋を対象とし たものであり、2019 年度日本建築学会大会で発表した研究 ${ }^{13)}$ 14)15)を 再構成したものである。

\section{2. 調査方法}

\section{1 文献調查}

広島県の灰屋について、各種学会誌や郷土史、民家の関連書籍を 調査した。そのうち用途や材料、構法などについて記載のあった文 献 13 件 ${ }^{16)}$ 28) を対象に、灰屋の成り立ち、呼び名、立地、灰の作製 方法および利用方法、灰屋の使用材料、施工方法について調查した。

\section{2 実測調査および聞取り調査}

調查地は文献 ${ }^{16)}$ 19) 20) からの情報により、灰屋が比較的多く分布す るという広島県三次市、世羅郡、安芸高田市の周辺とした。対象と する地域を踏查したところ、三次市を中心に 65 件を確認しており、 特に三若町、有原町の美波羅川沿いと上田町に多く発見された。調 查の実施状況をFig. 1 およびTable 1 に記号を用いて示した。65 件 のうち、地域ごとの偏りが無いよう選択した 32 件を対象に実測調 查を行った。そのうち所有者に話を伺えた 17 件の灰屋については 建築年、用途、施工方法などについて聞取り調查を行った。

Fig. 2 に調查対象として最も一般的な灰屋の構成と調查を実施し た項目を示す。同図のように調查地域の灰屋は、腰から下が土・石 積み壁で構成され、軸組は湾曲した材が利用されていることに特徵 がある。実測調查では、各部の寸法、屋根・天井・壁の構成等に加 え、湾曲した材同士の接合部分や開口などにも着目した。

また、土・石積み壁の外観観察を行い、壁厚および高さの実測を

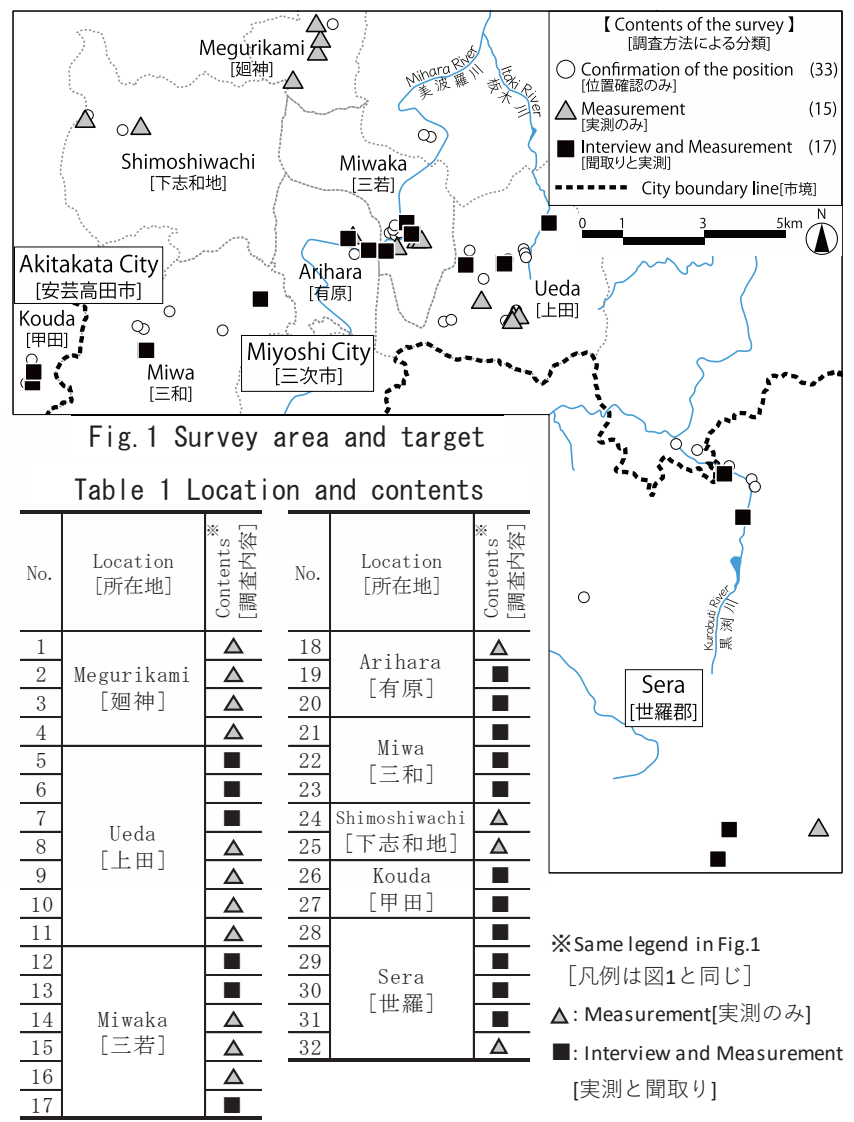

行った。さらに、土・石積み壁の一部が崩壊していた 6 件 (No. 1、5、 17、19、23、26)については、壁体内部の観察も行った。観察の項目 は、土・石積み壁の内部の垂直材の有無、石の寸法、土の性状、積 み方、土・石積み壁を覆う上塗土の有無である。なお、土の性状の 一つとして、土の色を標準土色帖に基づき記録した。以上の調査は 2018 年 11 月に実施した。

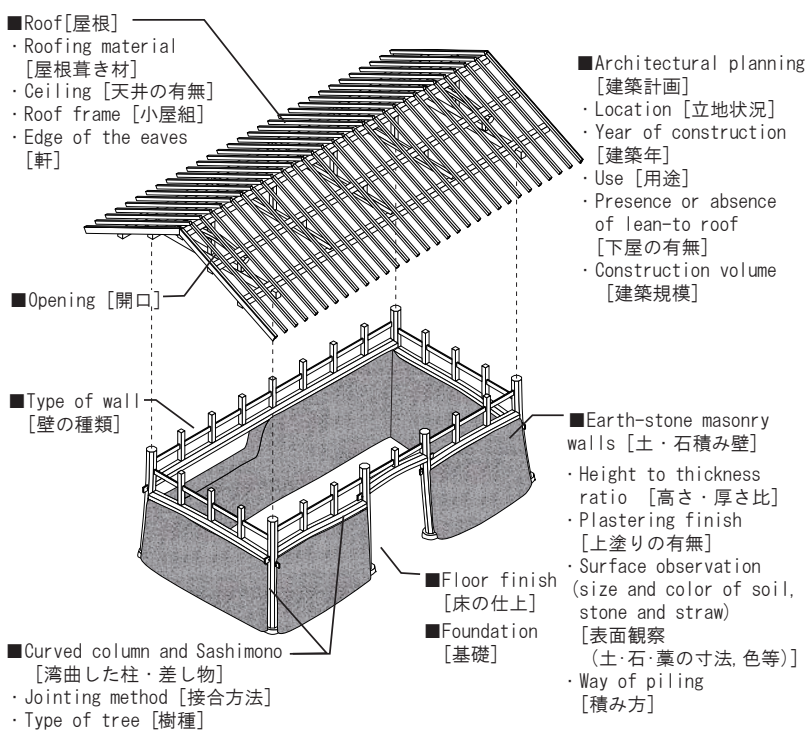

Fig. 2 Survey target(№. 26 as an example)

\section{3. 文献調査および聞取り調査の結果}

\section{1 広島県における灰屋の成り立ち}

日本では古くから各地で焼土注2)が行われており、兵庫、広島、鳥 取、大分では特に盛んで ${ }^{16)}{ }^{17)}$ 29)、広島に灰屋が多い理由はこれらの 歴史が影響している可能性が考えられる。また、慶長には安芸国吉 田から灰小屋を伝えた ${ }^{17)}$ とされる記録もあり、正確な成立年は不明 だが、肥料として焼土、草木灰を用いる文化があり、少なくとも 400 年以上前から、この地域には灰屋が存在したことが分かる。

確認できた文献の中で、灰屋の様子が分かる最も古い時代のもの は、今和次郎が描いた Fig. 3 に示すような灰屋 (1922 年) ${ }^{18)}$ であり、 次のような記述を残している。「・・・1悇程大きい家のものと思 はれる。(2)はちょうどこのころの自動車小屋の格好をしている。(3) も同様である。(4)は芝土を屋根にして棟木をもたせるのに柱を二本 立てている頗る原始的な作り方のものである。(5)板で作ったとて も奇妙な格好のものだ」。今回の調査では(1)以外の灰屋は確認できて いない。各年代の灰屋の様子として、Photo 1 (a) に阿佐群(現・広

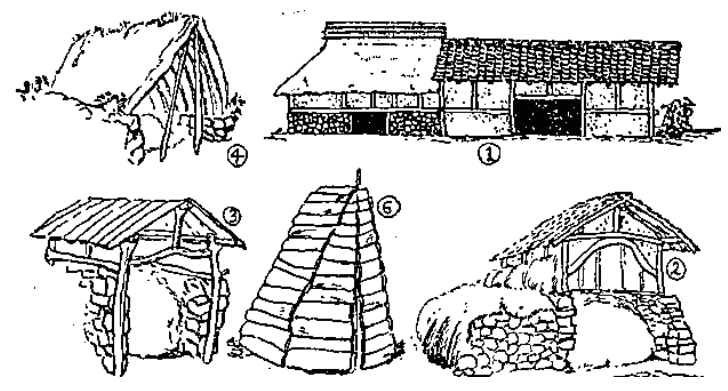

Fig. 3 Hanya in Bigo Futamigunn (1922) ${ }^{18)}$ 
島市安佐南区) の灰屋（1966 年） ${ }^{19)}$ を、(b) には世羅郡世羅西町 (現・世羅町) の灰屋（1978 年） ${ }^{20)}$ を示す。

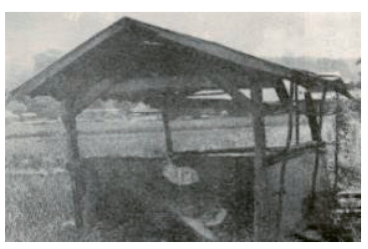

(a) Numata town $(1966)^{19}$ [沼田町]

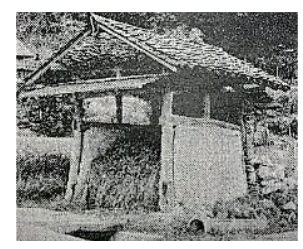

(b) Sera west town $(1978)^{20}$ [世羅西町]
Photo 1 Hanya in past

\section{2 灰屋の呼び名}

文献調查より、灰を焼く小屋には「はんや(灰屋)」19) 20)212 22) 23) 24) 25) 26) 27)「はいや (灰屋)」20)「はいごや(灰小屋)」16)21) 27)「はんごや (灰小屋)」16)222 23) 262 28)「はいやきごや(灰焼き小屋)」23)「はいなや」

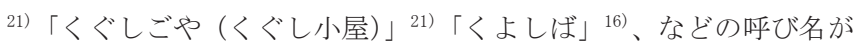
あることが明らかになった。

聞取り調查では「はんや」「はいごや」が呼称として最も多く聞 くことができた。

\section{3 灰の作製方法と利用方法}

文献調査より、灰は落ち葉やごみ、雑木（粗氺(そだ)、下ボク（げ ぼく)、ヤバとも呼ばれる ${ }^{28)}$ )を敷き、腐葉土などの土をかぶせて焼 いて灰を作製する 19) 20121) 22) 232 24) 25) 26) 27)。焼く期間は 1 日から 7 日 20) 28) だが大きいと 20 日かかるものもあった ${ }^{16)}$ 。土と落ち葉・枝木は土・ 石積み壁の高さまで積まれ ${ }^{18)}$ 、高さは 5〜6 尺ほどであった ${ }^{16)}$ 。灰 屋の常備道具のうち、Fig. 4 に示すエンボウと呼ぶ運搬具と灰カキ が使われていた ${ }^{26)}$ 。

灰の利用方法は、田畑の肥料が主であるが、特に麦、煙草、豆 ${ }^{16) 18)}$ 20125) 26) に用いられた。特に麦、豆は「八イハイといってまくだけで よく出来た」という言い伝えもあり、また、備後地方では在来の「備 中葉」という葉たばこの生産に草木灰を必要とした ${ }^{16)}$ 。

聞取り調查では、用途が灰の作製であったもののうち 3 件 (Table

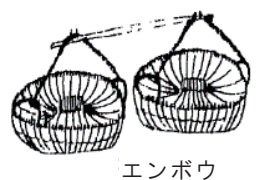

エンボウ

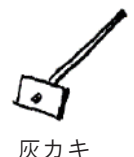

Fig. 4 Tools for the ash ${ }^{25)}$

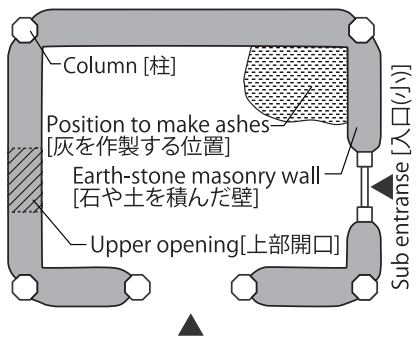

Main entrance [入口(大)]

(a)Floor plan[平面図]

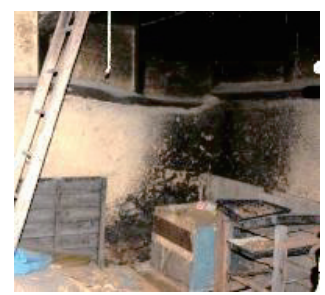

Photo 2 Place of ash made

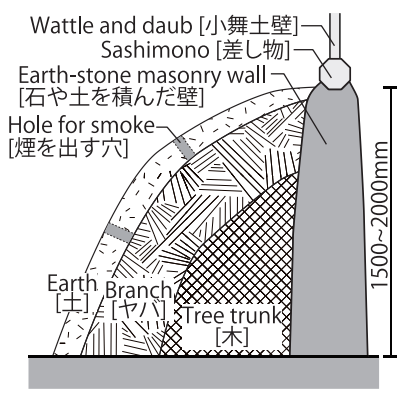

(b) Section [断面図]
Fig. 5 Method of making ash (No.20)
1 におけるNo.7、20、22)で灰に関する話を、特にNo. 20 については 以下のような詳しい話を聞くことができた。

灰の焼き方 :Fig. 5 (a) 平面図、(b)断面図にはNo. 20 の場合の灰の 作製位置、焼く際の材料の積み方を示す。灰の作製は、建物の隅で 行われており、木材、木の枝(ヤバ)を順に積み重ね、上から土や泥 を覆い被せて火を付ける。土・石積み壁に接する位置で高さが 1.5 〜 $2 \mathrm{~m}$ ほどになる。焼いている間、上に被せた土や泥により炎は殆ど 出ないが、小さな穴を数箇所開けて煙を出す。Photo 2 のように周 辺の壁面や軸組には黒いこげ跡が残っている。なお、材料や積み方

はNo.7、22 でも同様の内容を聞くことができた。

灰屋内で灰の作製を行うに至った経緯：戦前は田畑で灰を作製し ていたが、焼く際に煙が出ることに加え、灰は雨に濡れると使えな くなるため、屋内での作製・保管が望まれた。

\section{4 立地状況}

文献調査より、灰屋は火を扱うことから延焼の防止のために、山 裾の平場 ${ }^{18)}$ 、道のわき ${ }^{19)}$ 、田畑の中 18)21) や屋敷の隅 18)19)23) に建て られる。灰屋は耕作面積 $2000 \mathrm{~m}^{2}$ につき 1 棟が目安である ${ }^{16)}$ 。

実測調査の際に灰屋の立地状況を把握し、Fig. 6 に示すように、 主屋 (扊色塗) と扊屋 (黒塗)の位置関係を整理し、Table 2 に分類を 示した。その結果、Fig. 6 (a)のように敷地内だが、主屋から離れた 位置 (表中「離」) が 27 件、（b）のように主屋に隣接している場合 (表 中「隣」) が 2 件 (No. 20、No. 32) (c) のように田畑に建てられている 場合 (表中「田」) が 3 件 (No. 1、18、28)であった。また、公道に面 している場合 (表中「道」) が 14 件であり、雑木の搬入や灰の搬出

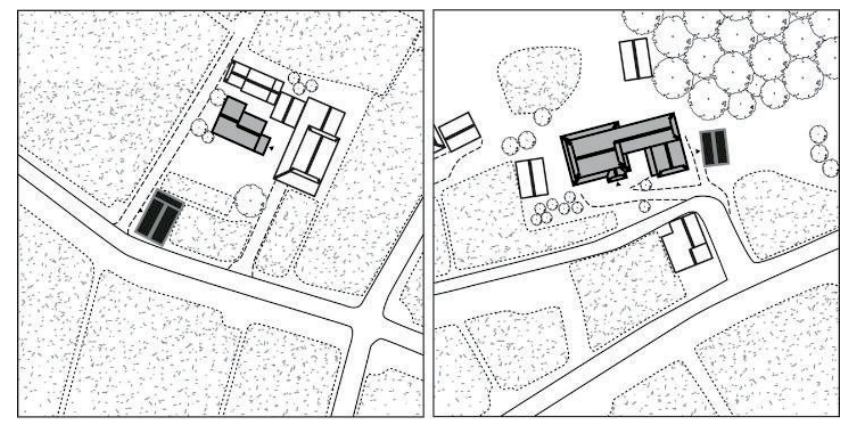

(a) Away from the main house, (b) Adjacent to the main house facing a public road[主屋から離れ、［主屋に隣接する場合] (No. 20) 公道に面する場合] (No. 24)

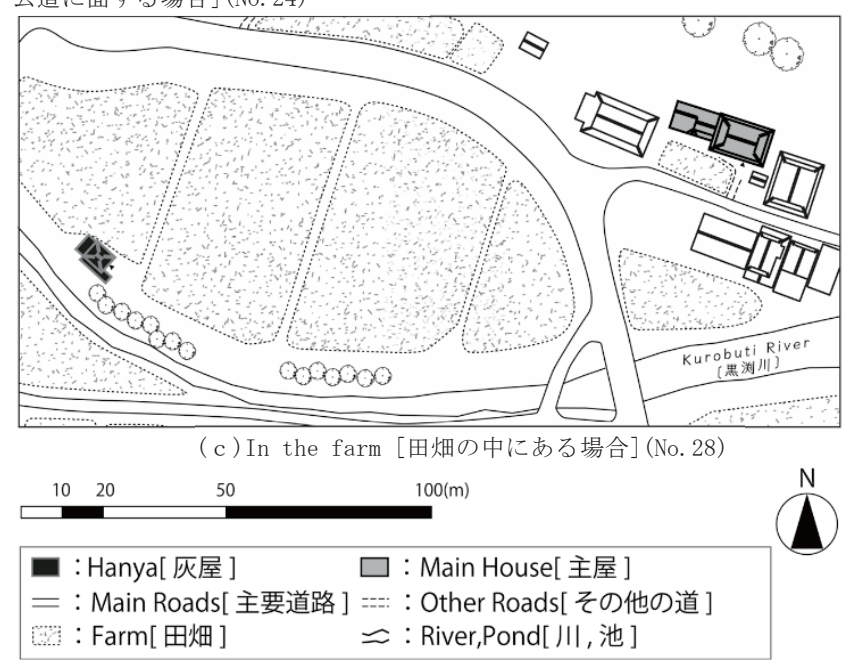

Fig. 6 Location of Hanya 
の利便性のためと考えられる。そのほかにも、文献 ${ }^{28)}$ にあように 傾斜地を掘りこんで高低差を利用している場合 (表中「高低」)が 6 件 (No. 9、12、18、20、31、32) 確認された。田畑に建てられたもの も合わせるとほとんどが主屋から離れており、延焼を防止するとい う文献の記載とおおむね致する結果となった。主屋に近い 2 件は、 延焼防止との関係は不明だが、高低差を利用して一段下がった場所 に立地していた。No. 14、15 およびNo. 22、23 のように、2 棟の灰屋 が並んで立っている例も確認された。

\section{5 建築年および用途の変化}

文献調查では、灰作製以外の用途では農機具の保管場所、脱穀作 業場、農作業の休㮃場所、ホイトウ (陪堂) 注3)が寝泊まりする場所、 ドブロクの密造所、戦後は住居とした場合 $\left.{ }^{25)} 28\right)$ もあった。特に化学 肥料の普及注 ${ }^{4)}$ にり、その役目を終えて用途が変わっていった ${ }^{16)}$ 。

聞取り調査の結果のうち、建築年を Fig. 7 に、建設当初の用途お よび現在の用途をFig. 8 に示寸。多くが現在の所有者の先代以前に 建てられたものであり、先代以前の方から聞いた情報が多かったた
め建築年・用途共に明確でないものもある。

Fig. 7 に示すように、最も新しいものは 40 年より前という回答で あり、40〜50 年以上前が 2 件、 $50 \sim 100$ 年以上前が 6 件、100 年以 上前が 3 件であった。

Fig. 7 より、建築当初は灰屋内で農業用の肥料として灰を作製し

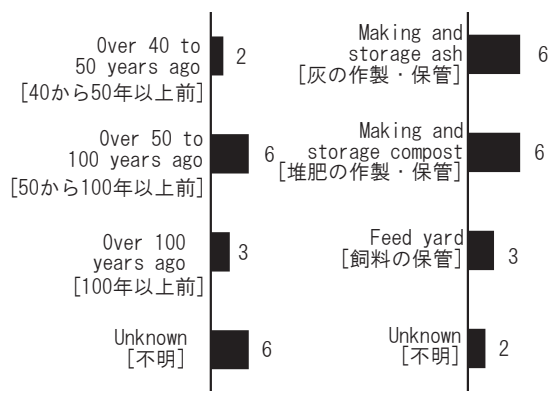

(a) At first

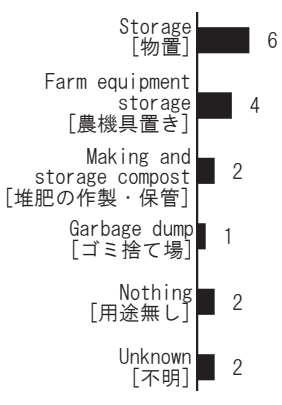

(b) Present
Fig. 7 Building years $\quad$ Fig. 8 Building use

Table 2 Composition of Hanya

\begin{tabular}{|c|c|c|c|c|c|c|c|c|c|c|c|c|c|c|c|c|c|c|c|}
\hline \multirow{4}{*}{ No. } & \multirow{4}{*}{ 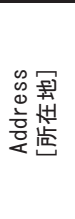 } & \multirow{4}{*}{ 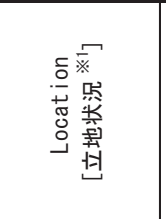 } & \multirow{4}{*}{ 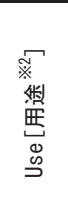 } & \multicolumn{4}{|c|}{$\begin{array}{c}\text { Scale } \cdot \text { Entrance } \cdot \text { Lean to roof } \\
{[\text { [規模・入口 } \cdot \text { 下屋 }]}\end{array}$} & \multicolumn{5}{|c|}{$\begin{array}{c}\text { Frame } \cdot \text { Wall } \\
\text { [軸組 } \cdot \text { 壁] }\end{array}$} & \multicolumn{5}{|c|}{$\begin{array}{l}\text { Roof and ceiling } \\
\text { [屋根 · 天井] }\end{array}$} & \multirow{2}{*}{\multicolumn{2}{|c|}{$\begin{array}{l}\text { Openings in } \\
\text { gable wall } \\
\text { [妻壁開口] }\end{array}$}} \\
\hline & & & & \multirow{2}{*}{\multicolumn{2}{|c|}{\begin{tabular}{|c|} 
Proportion $(\mathrm{mm})$ \\
[析行·梁間寸法]
\end{tabular}}} & \multirow{3}{*}{ 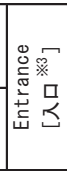 } & \multirow{3}{*}{ 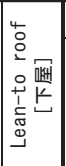 } & \multicolumn{2}{|c|}{ Column[柱] } & \multicolumn{3}{|c|}{ Sashimono[ [差し物] } & \multirow{3}{*}{$\begin{array}{c}\text { Roofing } \\
\text { material } \\
\text { [屋根莫材] }\end{array}$} & \multirow{3}{*}{$\begin{array}{c}\text { Roof } \\
\text { frame } \\
\text { [小屋組 } * 5]\end{array}$} & \multirow{3}{*}{ 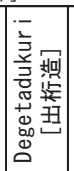 } & \multirow{3}{*}{ 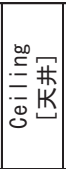 } & \multirow{3}{*}{ 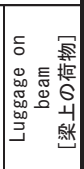 } & & \\
\hline & & & & & & & & 荬 & & 5 & & & & & & & & \multirow{2}{*}{ 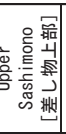 } & \multirow{2}{*}{ 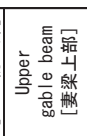 } \\
\hline & & & & \begin{tabular}{|c|} 
Ridge \\
direction \\
[桁行 ]
\end{tabular} & $\begin{array}{c}\text { Span } \\
\text { [梁間 }]\end{array}$ & & & 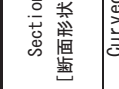 & 警 & 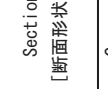 & $\begin{array}{l}\text { 总 } \\
\text { 言警 }\end{array}$ & $\mid$ & & & & & & & \\
\hline 1 & \multirow{4}{*}{ 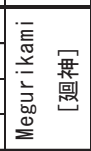 } & 田F & - & \begin{tabular}{l|l}
9128 \\
\end{tabular} & 4396 & 平 $H$ & - & 八 0 0cta & $\bullet$ & 八 0cta & $\bullet$ & $\bullet$ & 瓦 Roof tile & 折Ori - 京Ky & $\bullet$ & - & $\bullet$ & \begin{tabular}{l|l}
- & $F$ \\
\end{tabular} & Partial \\
\hline 2 & & 離Aw & - & 7465 & 4806 & 平 $\mathrm{H}$ & $\bullet$ & 丸 $\quad$ Round & $\bullet$ & 八 0cta & $\bullet$ & - & 瓦 Roof tile & 折 $0 \mathrm{ri}$ & - & - & $\bullet$ & - & - \\
\hline 3 & & 離Aw/道 & - & 10108 & 4684 & 平 $\mathrm{H}$ & - & 八 $\quad$ 0cta & $\bullet$ & 八 0 cta & $\bullet$ & - & 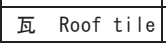 & 折Ori & - & - & - & - & Partial \\
\hline 4 & & 離Aw & - & 8684 & 5174 & 平 $\mathrm{H}$ & $\bullet$ & $\begin{array}{|ll|}\text { 八 } & \text { 0cta } \\
\end{array}$ & $\bullet$ & 八 0 cta & $\bullet$ & - & 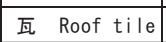 & 折Ori & - & - & $\bullet$ & - & - \\
\hline 5 & & 離Aw & 飼F & 7205 & 35 & 平 $\mathrm{H}$ & $\bullet$ & 八 $\quad$ 0cta & - 1 & 八 0 cta & $\bullet$ & - & 瓦 Roof tile & 折Ori - 京Ky & - & - & $\bullet$ & \begin{tabular}{l|l}
- & $\mathrm{P}$ \\
\end{tabular} & Partial \\
\hline 6 & & 離Aw & 灰As & 4300 & 3270 & 妻 $\mathrm{T}$ & - & 丸 $\quad$ Round & $\bullet$ & 丸 丸ound & $\bullet$ & & 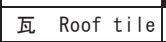 & 折0ri & - & - & $\bullet$ & - & - \\
\hline 7 & & 離Aw/道R & 灰As & \begin{tabular}{l|l}
6915 \\
\end{tabular} & 3255 & 平 $\mathrm{H}$ & $\bullet$ & 八 $\quad$ 0cta & \begin{tabular}{l|l} 
& 1
\end{tabular} & 八 0 cta & $\bullet$ & - & 瓦 Roof tile & 折Ori - 京Ky & $\bullet$ & - & $\bullet$ & - & Partial \\
\hline 8 & \begin{tabular}{|l|}
0 \\
0
\end{tabular} & 離Aw & - & 5200 & 3193 & 妻 $\mathrm{T}$ & $\bullet$ & 丸 $\quad$ Round & $\bullet$ & 丸 丸ound & $\bullet$ & - & $\begin{array}{|ll|}\text { 瓦 } & \text { Roof tile } \\
\end{array}$ & 折 $0 \mathrm{ri}$ & - & - & - & - & - \\
\hline 9 & & 離Aw/道R/高 & - & 51 & 3500 & 平 $H$ & $\bullet$ & 丸 $\quad$ Round & $\bullet$ & 丸 $\begin{array}{ll}\text { 丸ound } \\
\end{array}$ & $\bullet$ & $\bullet$ & 瓦 Roof tile & 折 $0 \mathrm{ri}$ & - & - & $\bullet$ & - & Whole \\
\hline 10 & & 離Aw & - & 59 & 3700 & 平 $\mathrm{H}$ & $\bullet$ & 丸 Round & $\bullet$ & 丸 $\quad$ Round & $\bullet$ & - & 瓦 Roof tile & 折Ori - 京Ky & $\bullet$ & $\bullet$ & - & - & - \\
\hline 11 & & 離Aw & - & 5955 & 3880 & 平H & - & 八 0 0cta & - & 八 0cta & $\bullet$ & - & トタン Tin-plate & 折0 $\mathrm{ri}$ & - & - & - & $\bullet$ & - \\
\hline 12 & & $\mathrm{~W} /$ 道R/高 & 肥Co & 71 & 5060 & 妻 T & $\bullet$ & 丸 $\quad$ Round & - & 丸 Round & $\bullet$ & - & 瓦 Roof tile & 折0 & - & $\bullet$ & - & - & - \\
\hline 13 & & 離Aw/道 & 肥Co & 5420 & 3508 & 妻 $\mathrm{T}$ & - & 丸 Round & $\bullet$ & 丸 \begin{tabular}{l|} 
丸ound \\
\end{tabular} & $\bullet$ & - & 瓦 Roof tile & 折0ri & - & - & - & - & 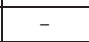 \\
\hline 14 & 把 & 離Aw & - & 6200 & 4180 & 平 $\mathrm{H}$ & - & $\begin{array}{|ll|}八 & 0 c t a \\
\end{array}$ & $\bullet$ & 丸 Æound & $\bullet$ & - & 瓦 Roof tile & Unknown & - & - & nknown & - & - \\
\hline 15 & III & 離Aw & - & 6680 & 4450 & 平 $\mathrm{H}$ & - & 丸 Round & - & 丸 \begin{tabular}{l|l} 
丸ound \\
\end{tabular} & $\bullet$ & - & \begin{tabular}{|ll} 
茅 & Thatch \\
\end{tabular} & 折Ori & - & - & - & - & - \\
\hline 16 & & 離Aw & - & 5490 & 3462 & 平 $\mathrm{H}$ & $\bullet$ & 丸 Round & - & 丸 $\begin{array}{l}\text { 丸ound } \\
\end{array}$ & $\bullet$ & - & 瓦 Roof tile & 折Ori & - & - & - & - & \\
\hline 17 & & 離Aw & 肥Co & 5790 & 3960 & 平 $\mathrm{H}$ & - & 丸 $\quad$ Round & $\bullet$ & 丸 \begin{tabular}{l|l} 
丸 \\
Round
\end{tabular} & $\bullet$ & - & Thatch & 折Ori & - & Loft & & - & \\
\hline 18 & & 田F/高低H & - & 10145 & 4030 & 平 $\mathrm{H}$ & - & 八 0 octa & \begin{tabular}{l|l} 
\\
\end{tabular} & 八 0 cta & $\bullet$ & - & 瓦 Roof tile & 折 $0 \mathrm{ri}$ & - & Loft & & $\bullet$ & Partial \\
\hline 19 & & 離Aw/道R & 肥Co & \begin{tabular}{l|l}
6215 \\
\end{tabular} & 4035 & 平 $\mathrm{H}$ & $\bullet$ & $\begin{array}{|ll|}\text { 八 } & \text { 0cta } \\
\end{array}$ & - 1 & 八 0 cta & $\bullet$ & - & 瓦 Roof tile & 折 $0 \mathrm{ri}$ & - & $\bullet$ & & - & Whole \\
\hline 20 & & 隣 $\mathrm{Ad} /$ 高低 $\mathrm{H}$ & 灰As & 7645 & 4300 & 平 $\mathrm{H}$ & $\bullet$ & $\begin{array}{|cc|} & \text { octa } \\
\end{array}$ & \begin{tabular}{l|l}
$\bullet$ & 1
\end{tabular} & 八 0 cta & $\bullet$ & - & 瓦 Roof tile & 折Ori - 京Ky & - & Loft & & \begin{tabular}{l|l} 
- & $\mathrm{P}$ \\
\end{tabular} & Partial \\
\hline 21 & & 離Aw & 肥Co & 6395 & 3960 & 平 $\mathrm{H}$ & $\bullet$ & 八 0 0cta & $\bullet$ & 八 0 cta & $\bullet$ & $\bullet$ & 瓦 Roof tile & 折Ori & - & - & $\bullet$ & \begin{tabular}{l|l}
- & $\mathrm{P}$ \\
\end{tabular} & Partial \\
\hline 22 & & 離Aw/道R & 灰As & 6300 & 4030 & 平 $\mathrm{H}$ & - & 八 0 0cta & $\bullet$ & 八 Octa & $\bullet$ & - & 瓦 Roof tile & 折Ori - 京Ky & - & - & & - & Whole \\
\hline 23 & & 離Aw/道R & 灰As & 5920 & 3980 & 平 $\mathrm{H}$ & - & $\begin{array}{|ll|}\text { 八 } & \text { 0cta } \\
\end{array}$ & \begin{tabular}{l|l}
0 \\
\end{tabular} & 八 0cta & $\bullet$ & - & 瓦 Roof tile & 折Ori & - & - & & \begin{tabular}{l|l}
- & $\mathrm{F}$ \\
\end{tabular} & Partial \\
\hline 24 & & 離Aw/道R & - & 8240 & 5965 & 平 $\mathrm{H}$ & $\bullet$ & 丸 $\quad$ Round & - & 丸 $\quad$ Round & $\bullet$ & - & 瓦 Roof tile & 折Ori & - & - & - & \begin{tabular}{l|l}
- & $\mathrm{P}$ \\
\end{tabular} & Partial \\
\hline 25 & & 離Aw & - & 7550 & 4320 & 平 $\mathrm{H}$ & - & 丸 $\quad$ Round & - & 丸 $\begin{array}{ll}\text { 丸ound } \\
\end{array}$ & $\bullet$ & - & \begin{tabular}{|ll} 
茅 Thatch \\
\end{tabular} & 折Ori & - & - & & $\bullet$ & - \\
\hline 26 & & 離Aw/道R & 飼F & 7810 & 3950 & 平 $\mathrm{H}$ & - & $\begin{array}{|ll|}八 & \text { Octa }\end{array}$ & - & 八 Octa & $\bullet$ & - & 瓦 Roof tile & 折Ori - 京Ky & - & - & $\bullet$ & - & - \\
\hline 27 & & 離Aw/道R & 不明Un & 5655 & 4010 & 平 $\mathrm{H}$ & $\bullet$ & 丸 $\quad$ Round & - & 丸 $\begin{array}{ll}\text { 丸ound } \\
\end{array}$ & $\bullet$ & - & 瓦 Roof tile & 折 $0 \mathrm{ri}$ & - & - & $\bullet$ & - & - \\
\hline 28 & & 田F & 灰As & 3675 & 2645 & 妻 $\mathrm{T}$ & $\bullet$ & 八 0 0cta & $\bullet$ & 八 0 cta & $\bullet$ & - & \begin{tabular}{|ll} 
茅 & Thatch
\end{tabular} & 折Ori & - & $\bullet$ & & - & - \\
\hline 29 & & 離Aw & 不明Un & 4030 & 3035 & 妻 $\mathrm{T}$ & - & 八 0 0cta & - 1 & 八 0cta & - & - & $\begin{array}{|ll|}\text { 茅 } & \text { Thatch } \\
\end{array}$ & 折 $0 \mathrm{ri}$ & - & - & - & - & - \\
\hline 30 & 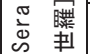 & 離Aw/道R & 飼F & 6130 & 4980 & 平H & - & 丸 Round & - & 八 Octa & $\bullet$ & $\bullet$ & \begin{tabular}{|ll} 
ZL & Cement \\
-r & -plate
\end{tabular} & 折 $0 \mathrm{ri}$ & - & Loft & & - & - \\
\hline 31 & & 隣AW/道R/高低H & 肥Co & 5185 & 4420 & 妻 T & - & $\begin{array}{|ll|}\text { 八 } & \text { 0cta } \\
\end{array}$ & - & 丸 丸ound & - & - & トタンTin-plate & 折Ori - 京Ky & - & - & - & - & Whole \\
\hline 32 & & 隣 $\mathrm{Ad} /$ 道R/高低H & - & \begin{tabular}{l|l}
5935 \\
\end{tabular} & 2845 & 平H & - & $\begin{array}{|ll|}\text { 石 Stone } \\
\end{array}$ & -1 & 八 0cta & - & - & 瓦 Roof tile & 折0 $\mathrm{ri}$ & - & - & & - & - \\
\hline
\end{tabular}

※1 田F=田んぼの中 In farm、離Aw=主屋から離れた敷地内 Away from the main house、隣Ad=主屋に隣接 Adjacent to the main house、

道 $R=$ 道路脇 Roadside, 高低H=高低差のある場所 With height difference

$※ 2$ 灰As=灰の作製 Making and storing ashes、肥Co=肥料・堆肥小屋 Making and storing compost、飼F=飼料置き場 Feed yard、不明Un=用途不明 Unknown、 $-=$ 聞き取り調查実施無し No interviews $※ 3$ 平 $\mathrm{H}=$ 平入り Enter from the side which runs parallel to the roof's ridge. 妻 $\mathrm{T}=$ 妻入りEnter from the gable end side

$※ 4$ 丸 Round=丸太 Round、八 Octa=八角形 Octagon、石 Stone=石材を使用 Using stone

※5 折Ori=折置組の特徴ありFeature of the “Oriokigumi”、京Ky=京呂組の特徵ありFeature of the “Kyourogumi” 
ていたものが 7 件、肥料・堆肥の作製・保管に用いたものが 6 件、 その他家畜の餌等の飼料置き場が 3 件であった。現在は、灰や肥料 の作製はほとんど行われておらず、用途は農機具小屋や物置に変わ っている。

\section{6 灰屋の構成と施工方法および生産体制}

文献調査より、灰屋の構成は柱梁の軸組に屋根をかけ、腰まで土・ 石積み壁とする方法が共通している 16) 18) 19) 20) 21) 222 23) 24) 25) 27) 28)。灰屋 の四隅の柱は大きな栗の木を使い、広島市安佐北区白木町あたりで は「灰小屋柱」といって栗の木を林中に特別に残して喬木に育てて いた ${ }^{16)}$ 。屋根材は菜や茅 ${ }^{16)}$ 、瓦が普及してからは防火のために瓦を 用いる場合が多い 19)2027)。規模は 4 間 $\times 3$ 間、3 間 $\times 2$ 間など様々で ある ${ }^{25)}$ 。各文献で述べられる材料および構法に関する特徴は Photo 1 の灰屋にも共通して確認できる。

灰屋のつくりについて、「灰小屋が豪壮だと良い百姓であり、古い 農家だ」、「白木町あたりでは良い葍屋根職人がいて灰小屋の屋根に 名人芸が込められていた」、「灰小屋の大小、その数によって家格・ 財力が想定されるほどであった」など ${ }^{16)}$ 、灰屋は農家にとって豊か さや百姓としての能力の高さを示寸重要な位置づけになっている地 域もあることが分かる。

聞取り調查では、No. 7、20の 2 件で話を聞くことができたが、現 在の所有者自身が施工に関わったものはなく、先代や先々代から聞 いたものであった。No. 7 の場合は軸組をつくるのは大工で、その後 石や土を積み、小舞土壁は左官職人が行っていた。No. 20 の場合は、 近所の大工に依頼して建てていた。土・石積み壁は、専門の職人が おり、石と土を交互に積み、外側に土を付けた。また、No. 6 の施工 者は、大工であった現在の所有者の祖父だとわかっている。

柱や梁に用いられる湾曲した木材は、近隣の山から入手したもの で(No.6、21)、腐朽しにくい栗の木が好まれた（No.20）、というこ とであった。

石は、No. 7 の灰屋では近隣の山から入手していた。

土は、近くにあるものを用いたこと（No.6、7)、粘りのある赤土が 好まれたこと (No. 13、20)、粘土を用いていたこと (No. 12)、土を使 う際には赤土に橖を混ぜて踏んで使ったこと(No.13)、が分かった。

また、上塗り用の土は田んぼの土と葍を混ぜたものを用いていた (No. 22)。

\section{4. 実測調査結果}

\section{1 平面規模と入口および下屋の有無}

灰屋の実測調查の結果を Table2 に示す。Fig. 2 には基本的な平屋 で平入の灰屋を、Fig. 9 には調査で確認された灰屋のうち特徵的な つくりをもつ灰屋として、（a）平屋平入で下屋あり、(b)入母屋茅莫 で妻入、(c) 高低差を搬入口に利用、(d) 2 階建て、の合計 4 タイプ を示す。

土・積み壁で囲まれる空間の平面規模は、最少が No. 28 の桁行 $3675 \times$ 梁間 $2645 \mathrm{~mm}\left(11 \mathrm{~m}^{2}\right)$ 、最大が No. 3 の桁行 $10108 \times$ 梁間 4684 (47 $\left.\mathrm{m}^{2}\right)$ 、平均は $27.9 \mathrm{~m}^{2}$ であった。寸法だけでみると桁行は最大が $10145 \mathrm{~mm}$ 、最小が $3675 \mathrm{~mm}$ 、平均は $6542 \mathrm{~mm}$ 、梁間は最大 $5965 \mathrm{~mm}$ 、最 少が $2645 \mathrm{~mm}$ 、平均は $4044 \mathrm{~mm}$ と、桁行は大きく幅があるが、梁間は 幅が少ない結果となった。

入口は、妻入が 7 件、平入が 25 件と、平入が多かった。下屋は Photo 3 (a) に示寸柱だけの場合が 5 件、（b）に示寸壁で囲まれた 空間となっている場合が 10 件であった。下屋の壁は、土・石積み壁 の場合や小舞土壁・トタン張りの場合などがあった。下屋空間の用 途は、稲木とおもわれる木材や葍、肥料、農薬、農具・農機具の保 管が主だが、風呂場 (No. 7) になっている場合もあった。

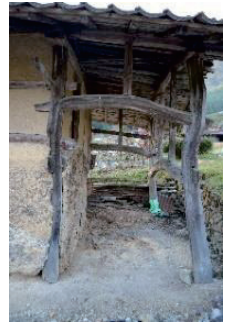

(a) Only column (No. 19)

[柱のみの場合］

Photo 3

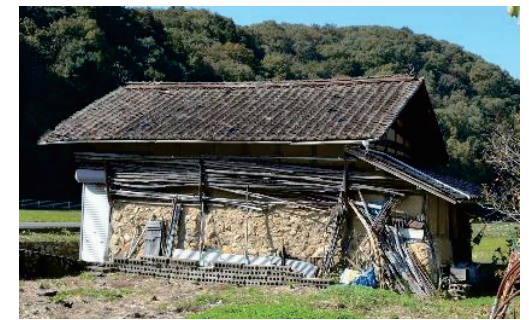

(b) Earth-stone masonry wall (No. 24) [土・石積み壁がある場合］

\section{Pattern of lean-to roof}

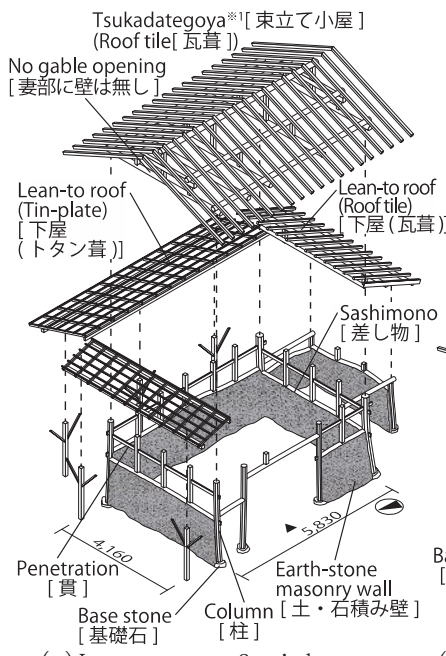

(a) Lean-to-roof with earth-stone masonry wall [土・石積み壁の下屋あり］(No. 27)

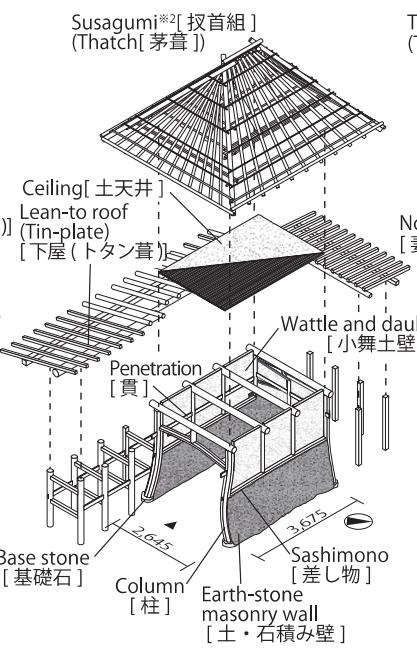

(b) Thatched roof and ceiling [入母屋茅莫で土天井あり]

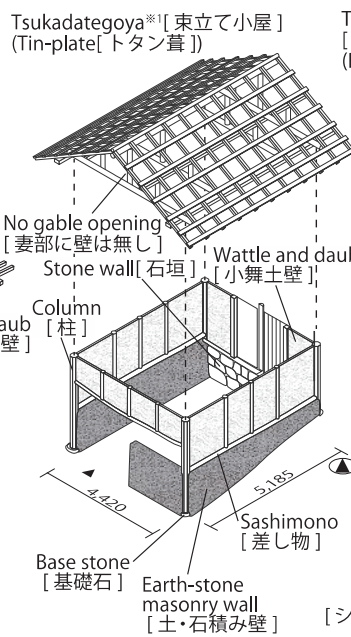
masonry wall

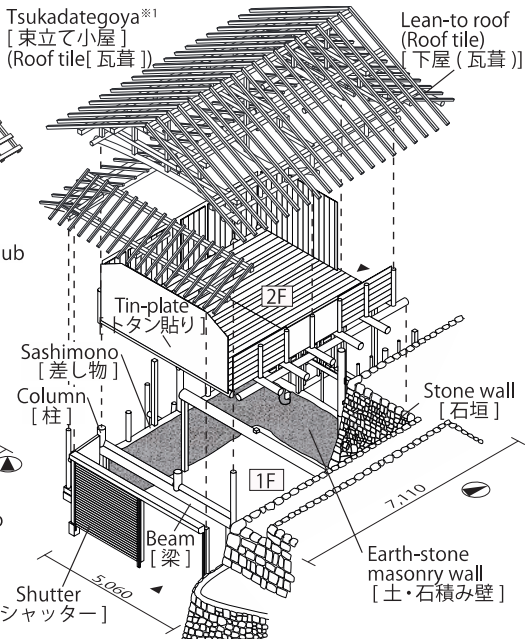

(d) Use to height difference (two storey building)

(Opening for carry in)

[高低差利用(搬入口)］(No. 31）［高低差利用(2 階建て)］(No. 12) Fig. 9 Isometric drawings of the four types of Hanya
$※ 1$ Roof frame using strut mainly $※ 2$ Roof frame using principal rafter 


\section{2 床・基礎・軸組}

床は、基本的に土間だが特に三和土のような仕上げを施した様子 は確認できなかった。

すべての灰屋が柱梁の木造軸組構造であり、基礎は石の上に柱を 載せる石場立て (土台・足固め無し) と、地面に直に柱を立てる場合 とがあった。高低差を利用した 2 階建ての場合 (No. 12、Fig. 9(d)) は、床梁を斜面の石垣に載せていることが確認できた。

土・石積み壁の上部には横架材が架けられており、文献調查およ び聞取り調査では名称の情報は得られなかった。そこで、本報では この横架材を “差し物”と呼ぶこととした。差し物の上には垂直材 が並び、柱と共に小屋組を支えている。小屋組が折置組の場合は小 屋梁を通じて、京呂組の場合は敷桁を通じて屋根荷重を受けている。

柱は、室内側は塗り込めてあり屋外は表しとなっている。また、 差し物は下部半分が土・石積夕壁に埋まっている。柱・差し物およ び入口上部のまぐさはN No. 31、32 を除くほぼすべての灰屋で湾曲材 が用いられている。柱に用いる際には、Fig. 9 (c)に表れているよう に上部が狭く、足元が広くなるように使われていた。差し物にはそ の多くが上側に膨らむように用いられ、上部の壁・垂直材を支える うえで構造的に安定なつくりになっている。また、妻梁、本梁、二 重梁、大桁などにも用いられる場合が確認できたが、柱および差し 物に比べるとそれ以外の材は直線材が多い。

柱および差し物は丸太材のまま使う場合と、Photo 6 柱・梁の接 合方法に示すように断面形状が八角形程度になるよう加工した材 を用いる場合があった。八角の場合はちょうなではつった痕跡が確 認できる場合が多い。

\section{3 土・石積み壁}

\section{(1) 壁の構成}

壁は、地面から差し物までは土・石積み壁が、差し物から梁桁ま ではFig. 9 (b) (c)のように小舞土壁、(d) 板・トタン貼り、(a) 壁無 し、などの例が確認できた。2 階建ての場合 (No. 12)でも、土・石積 み壁は 1 階の差し物までで基本的な平屋と違いはなかった。

\section{(2) 厚さおよび高さ}

Table 3 に土・石積み壁の厚さおよび高さをまとめた。厚さは、 壁上部へいくにつれて薄くなる場合がほとんどであり、下部と上部 の差は平均して $150 \mathrm{~mm}$ 程度であった。壁の高さは、1000〜2200 mmで あった。

\section{(3) 使用材料}

Table 3 に土・石積み壁の実測調査および観察の結果を示す。土・ 石積み壁に積まれた石は、比較的小さな石を用いる場合から、最大 寸法 $400 \mathrm{~mm}$ 程度の大きい石を用いる場合があった。石の形状は、角 が尖っているものと、丸いものがあり、尖っているものは山から、

丸いものは川から採取した可能性が考えられる。

土の色は、Table 3 に示寸ように浅黄橙 4 件、にぶい黄橙 4 件、 明黄褐 1 件、黄橙 1 件、橙 1 件が確認でき、中国地方に広く分布す る褐色森林土と考えられる。土・石積み壁に積まれた土、および上 塗土とも、切㩰が混入されていることが確認できた。

\section{（4）壁体内の垂直材}

壁体の内部は、Photo 4(a)のように壁の一部が崩壊した箇所や(b) 亀裂部分から観察を行った。観察した 11 件のうち 8 件で垂直の木 材が確認できた。
木材の径は $\phi 90 \mathrm{~mm}$ 程度からさらに細いものがある。材の位置は Photo 4(b)に示すように差し物上部の柱と位置を揄える場合や、壁 の中に均等な間隔でいれる場合があり、No. 19 や 23 では壁の崩壊に 伴い垂直材が差し物から沈降しているが、垂直材にホゾを、差し物 にホゾ穴を確認できた。これら土・石積み壁内の垂直材について、 間柱のように上部の荷重を支えている場合や、土・石積み壁の施工 時のガイドとして用いられていた場合などが考えられるが明確な役 割は不明である。垂直材の周辺は土が薄くなり亀裂が生じや寸かっ たため、内部が観察できたと考えられる。

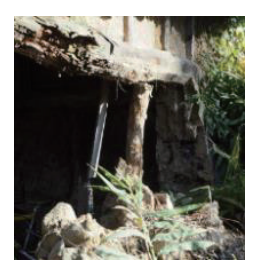

(a) From collapse (No. 23) [崩壊部分から観察］

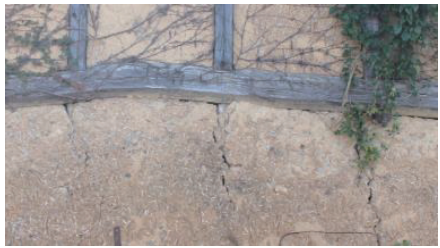

(b) From cracks (No. 3)

[亀裂部分から観察]
Photo 4 Vertical timber conserved in wall

\section{（5）石および土の積み方}

Table 3 の右側[積み方]の欄に示すように、ほとんどの壁におい て石の存在が確認できた。多くの場合で石と土を交互に積んで壁の ベースをつくり、その表面を土で覆って仕上げとしていた。上塗土 がある場合は、内部の土・石積み部分は判別できない場合もあった。

石および土の積み方を立面的にみて、以下の (1) (2)ように大きく 2 通りに分類し、Table 3 中に示した。壁の位置、室内側・外側など で異なる場合は、分けて示している。なお、高低差のある地形で石 垣を壁の一部に利用する場合があったが、これは以下の分類には含 めていない。

(1) 石の大きさ・積み方ともにまばらである場合 (15 件)

土は無い場合が 2 件、少ない場合が 2 件、多い場合が 11 件

(2) 壁の上部ほど石が小さくなる場合 (4 件)

土は少ない場合が 1 件、上部ほど多い場合が 3 件

Fig. 10（a）（b）に(1)石がまばらに積まれた様子を、(c) に(2)上部 ほど小さい石が積まれた様子を示す。上部の石ほど小さくなる (c) のような場合は、下部の石が基礎としての役割も担っている可能性 も考えられる。

壁の一部が崩壊して断面を観察できた 6 件をみると、使用される 石の寸法によって、1 列または 2 列でまばらに積まれており、同じ 灰屋でも壁によって異なる積み方が観察できる場合もあった。

また、 4 件において奈良の土積み壁 ${ }^{7)}$ にみられた水平の区切りが

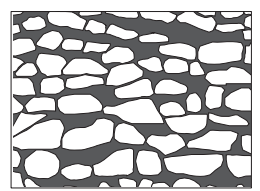

(a) Sparse and little earth [まばらで土少め (No. 26) ]

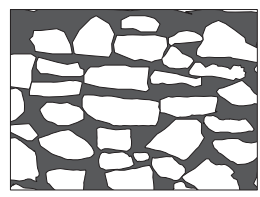

(b) Sparse and much earth [まばらで土多め (No. 28) ]

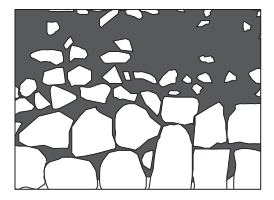

(c) Top part of the stone is smaller [上部ほど石が小さい (No. 24) ]
Fig. 10 Type of stone piling 
確認できた。これは、湿った土を一度に高く積むと垂れ下がるため、 一定高さごとに乾燥工程を入れた跡であると考えられ、石を用いな いか、石を用いていても特に土が多かった可能性が考えられる。

\section{(6) 上塗り}

上塗土の痕跡の有無を Table 3 の右側に示した。内外ともに痕跡 のある場合が多かったが、室内側では上塗土がなく石がむき出しに なっている場合もあった。表面を覆う上塗土は、経年によってはが れることが聞取り調査でもわかっている。

\section{4 屋根・天井および軒}

屋根形式は入母屋と切妻があり、Table 2 に示すように、入母屋
は寸べて茅莫で 5 件、切妻の場合の蕞き材は瓦が 24 件、トタンが 2 件、波板スレートが 1 件であった。なお、茅莫の場合、いずれも現 在は外側に金属板が被せられている。

室内の梁桁の取り合いを分類したものを Fig. 11 に示す。妻壁の 梁と桁の取り合いは、出桁造りの (6)(7)(8)を除く全件で、折置組の特 徵である柱頭に梁、その上に桁というつくりになっていた。

しかし、室内の梁と桁、間柱の取り合いは様々な種類が確認され た。妻壁と同様に折置組なのは(1)(2)(3)(4)の 4 種類で中引梁があるの は(1)と (2)で、(2)は小屋梁が無い箇所に束を立てるために用いられて いた。梁の先端をホゾ加工して柱に差込んで留めてあるのは(5)で、

Table 3 Results of the survey on earth and stone masonry wall

\begin{tabular}{|c|c|c|c|c|c|c|c|c|c|c|c|c|c|c|}
\hline \multirow{4}{*}{ №. } & \multirow{4}{*}{ 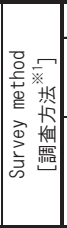 } & \multicolumn{5}{|c|}{ Thickness and height of walls [壁の厚さおよび高さ] } & \multicolumn{8}{|c|}{ Building construction, materials and construction method [構法, 材料および施工方法と関係する情報 $]$} \\
\hline & & \multirow{2}{*}{\multicolumn{2}{|c|}{$\begin{array}{l}\text { Thickness } \\
\text { [厚さ } t](\mathrm{mm})\end{array}$}} & \multirow{3}{*}{\multicolumn{2}{|c|}{$\begin{array}{l}\text { Height } \\
\text { [高さ } h] \\
(\mathrm{mm})\end{array}$}} & \multirow{3}{*}{$\begin{array}{l}\text { Height to } \\
\text { thickness } \\
\text { ratio } \\
\text { [壁厚高さ比] } \\
(h / t)\end{array}$} & \multirow{3}{*}{ 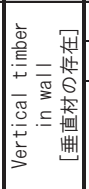 } & \multicolumn{2}{|c|}{ Materials [使用材料］ } & \multicolumn{3}{|c|}{ Way of piling [積み方 $]$} & \multirow{2}{*}{\multicolumn{2}{|c|}{$\begin{array}{c}\text { Final coating } \\
\text { earth } \\
\text { [上塗土の有無] }\end{array}$}} \\
\hline & & & & & & & & Stone [石] & Earth $[ \pm]$ & \multirow[b]{2}{*}{ Stone $e^{* 2}[$ 石 $]$} & \multirow[b]{2}{*}{ Earth*3 $[ \pm]$} & \multirow{2}{*}{ 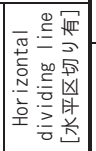 } & & \\
\hline & & $\begin{array}{l}\text { Lower } \\
\text { part } \\
\text { [下部] }\end{array}$ & $\begin{array}{c}\text { Top } \\
\text { part } \\
\text { [上部 }]\end{array}$ & & & & & $\begin{array}{c}\text { Maximum size } \\
\text { [最大寸法] (mm) } \\
\text { (Height, Width } \\
\text {, Length) }\end{array}$ & \begin{tabular}{|c|} 
Color name \\
and sample \\
[色名称および \\
色見本 $]$
\end{tabular} & & & & $\begin{array}{l}\text { Outside } \\
\text { [外壁] }\end{array}$ & $\begin{array}{l}\text { Inside } \\
\text { [内壁] }\end{array}$ \\
\hline 1 & 断 & 440 & 270 & \multirow{2}{*}{\multicolumn{2}{|c|}{$\begin{array}{l}1950 \\
1750\end{array}$}} & $4.4 \sim 7.2$ & 0 & - & - & Lower:Sparse, Top:x & Lower:Wi thout, Top: $x$ & - & \multicolumn{2}{|c|}{ Lower: $x$} \\
\hline 2 & 外 & 400 & 250 & & & 4. $4 \sim 7.0$ & - & - & - & Lower:Sparse, Top:x & Lower:Wi thout, Top: $x$ & - & Lower: $x$, & Top:- \\
\hline 3 & 外 & - & - & \multicolumn{2}{|l|}{2030} & - & $\bullet$ & - & - & Big $\rightarrow$ Small & Little $\rightarrow$ Much & - & Lower: $\mathrm{x}$ & $\bullet$ \\
\hline 4 & 外 & - & - & \multicolumn{2}{|l|}{2200} & - & - & - & - & \multicolumn{2}{|c|}{ Sparse } & - & \multicolumn{2}{|c|}{ - } \\
\hline 5 & 断 & 430 & 340 & 1930 & & 4. $5 \sim 5.7$ & - & 265,145 & $\begin{array}{l}\text { 7. } 5 \text { YR8 } / 4 \\
\text { 浅黄橙 }\end{array}$ & & Much & - & - & \\
\hline 6 & 外 & 350 & 270 & 1460 & & 4. $2 \sim 5.4$ & ๑ & - & - & & & - & 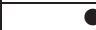 & \\
\hline 7 & 多 & 520 & 360 & \begin{tabular}{|c|} 
Entrance right \\
入口右側
\end{tabular} & 1620 & 3. $1 \sim 4.5$ & $-\pi$ & 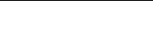 & 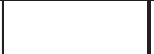 & & & 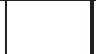 & & \\
\hline 1 & "Tr & 500 & 300 & $\begin{array}{c}\text { Entrance left } \\
\text { 入口左側 }\end{array}$ & 1640 & 3. $3 \sim 5.5$ & 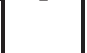 & & 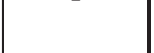 & & & 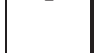 & ( & \\
\hline 8 & 外 & 350 & 250 & 1400 & & 4. $0 \sim 5.6$ & - & - & - & & & - & 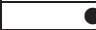 & \\
\hline 9 & 外 & 500 & 210 & South 南面 & 1730 & $3.5 \sim 8.2$ & - & - & - & East:Sparse & Much & 9 & 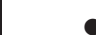 & \\
\hline & & 500 & 210 & East 東面 & 1650 & 3. $3 \sim 7.9$ & & & & Other: Sparse & (miven & & & \\
\hline 10 & 外 & & & & & & Wi tho & ut earth-stone & masonry walls \pm & ·石積み壁が存在せず & & & & \\
\hline 11 & 外 & 500 & 260 & 1750 & & $3.5 \sim 6.7$ & - & - & - & & & - & C & \\
\hline 12 & 外 & - & 350 & 2050 & & 5.9 & - & - & - & & & - & - & \\
\hline 13 & 外 & - & - & 1500 & & - & - & - & - & & & - & C & D \\
\hline 14 & 外 & - & - & 1540 & & - & - & - & - & & & - & - & U \\
\hline 15 & 外 & & & & & & Wi tho & ut earth-stone & masonry walls \pm & ·石積み壁が存在せず & & & & \\
\hline 16 & 外 & 365 & 235 & 1650 & & $4.1 \sim 8.3$ & 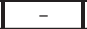 & 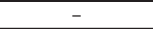 & - & Inside:Sparse & Inside:Much & 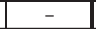 & e & $x$ \\
\hline 17 & 断 & 440 & 210 & West 西面 & 1870 & 4. $3 \sim 8.9$ & - & - & - & West:Big $\rightarrow$ Smal I & West:Little $\rightarrow$ Much & - & $x>0$ & \\
\hline 11 & 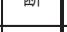 & 600 & 190 & North 北面 & 1900 & 3. $2 \sim 10$ & 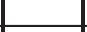 & 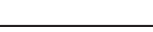 & - & Other:Sparse & Other:Much & - & & \\
\hline 18 & 㔔 & 480 & 250 & $\begin{array}{c}\text { Entrance right } \\
\text { 入口右側 }\end{array}$ & 170 & 4. $1 \sim 7.9$ & 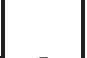 & Smollut & 10YR7/3 & Snarce & Outside:Little & 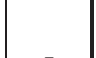 & - & $x$ \\
\hline 10 & TT & 500 & 250 & $\begin{array}{c}\text { Entrance left } \\
\text { 入口左側 }\end{array}$ & | 1070 & 3. $9 \sim 7.9$ & & होila & にぶい黄橙 & opar se & Inside:Much & & 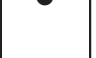 & 等 \\
\hline 19 & 断 & - & - & - & & - & 0 & - & \begin{tabular}{|l|} 
10YR7/6明黄褐 \\
\end{tabular} & Sparse & Much & - & 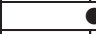 & 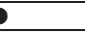 \\
\hline 20 & 外 & 330 & 330 & 1980 & & 6. 0 & - & - & - & $\mathrm{Big} \rightarrow$ Small & Little & - & $\bullet$ & $\begin{array}{c}x \\
\text { (Partial) }\end{array}$ \\
\hline 21 & 外 & 400 & 280 & 1710 & & $4.3 \sim 6.1$ & - & 250,200 & - & Sparse & Much & - & 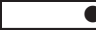 & \\
\hline 22 & 外 & 530 & 270 & 1920 & & $3.6 \sim 7.1$ & - & - & - & & & - & C & \\
\hline 23 & 断 & 510 & 270 & 2110 & & 4. $1 \sim 7.8$ & - & 300,200 & 7. 5YR8/4浅黄橙 & Sparse & Much & - & 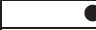 & \\
\hline 24 & 外 & - & 240 & 1000 & & 4. 2 & - & 370,300 & $\begin{array}{c}10 Y R 7 / 4 \\
\text { にぶい黄橙 } \\
\end{array}$ & Big $\rightarrow$ Smal I & Little $\rightarrow$ Much & - & - & \\
\hline 25 & 外 & & & & & & Witho & ut earth-stone & masonry walls 土 & 石積み壁が存在せず & & & & \\
\hline 26 & 断 & - & 300 & 2060 & & 3. $4 \sim 6.9$ & - & $350,250,200$ & - & Sparse & Little & - & - (Par & tial) \\
\hline 27 & 外 & 365 & 235 & 1510 & & $4.1 \sim 6.4$ & - & - & 10YR8/3浅黄橙 & Sparse & Much & - & - $(\mathrm{Par}$ & tial) \\
\hline 28 & 外 & 450 & 300 & 1480 & & 3. $3 \sim 4.9$ & - & 300,190 & 7. 5YR8/6浅黄橙 & Sparse & Much & - & $x$ & \\
\hline 29 & 外 & 400 & 340 & 1370 & & 3. $4 \sim 4.0$ & - & 380,300 & 10YR8/6黄橙 & Sparse & Much & - & - & $x$ \\
\hline 30 & 外 & 350 & 275 & South 南面 & 1620 & 4. $6 \sim 5.9$ & - & - & $25 \mathrm{YR6} 68$ 橙 & & & - & $8+x$ & \\
\hline 30 & 外 & 230 & 170 & East 東面 & 1520 & $6.6 \sim 8.9$ & - & - & 2. $51 k 0 / 8$ 䅱 & & & - & 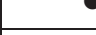 & \\
\hline 31 & 外 & 340 & 240 & $\begin{array}{l}\text { South west } \\
\text { 南西面 }\end{array}$ & 1370 & 4. $0 \sim 5.7$ & - & - & 10YR6/4 & & & - & 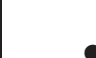 & \\
\hline (3) & 31 & - & 340 & $\begin{array}{l}\text { South east } \\
\text { 南東面 }\end{array}$ & 1160 & 3. 4 & & & にぶい黄橙 & & & & ( & \\
\hline 32 & 外 & 250 & 250 & 1050 & & 4. 2 & - & - & $\begin{array}{c}10 Y R 7 / 2 \\
\text { にぶい黄橙 }\end{array}$ & & & - & U & - \\
\hline $\begin{array}{l}\text { 注) } \\
\text { ※1 } \\
※ 2\end{array}$ & $\begin{array}{l}\text { Explan } \\
U=\text { Exi } \\
\text { 断:Cr } \\
\text { Spars } \\
/ \mathrm{Big} \\
/ \mathrm{x}: \mathrm{N}\end{array}$ & $\begin{array}{l}\text { latory no } \\
\text { stence o } \\
\text { oss-sect } \\
: \text { The sto } \\
\rightarrow \text { Small: } \\
\text { lot sure }\end{array}$ & $\begin{array}{l}\text { tes of a } \\
\text { nonexi } \\
\text { ional ob } \\
\text { enes are } \\
\text { The top } \\
\text { if the } s\end{array}$ & $\begin{array}{l}\text { I I common symbols } \\
\text { stence unknown 有 } \\
\text { servations from t } \\
\text { sparsely and irre } \\
\text { part is made of } \\
\text { tone is there. 石力 }\end{array}$ & $\begin{array}{l}\text { 全項 } \\
\text { 無が不 } \\
\text { the col } \\
\text { egular } \\
\text { smaller } \\
\text { があるか }\end{array}$ & $\begin{array}{l}\text { 頁目共通の記号 } \\
\text { 下明、ー ー ハイフ } \\
\text { Ilapsed area a } \\
\text { ly piled. まばり } \\
\text { r stones. 上部| } \\
\text { かどうか不明 }\end{array}$ & $\begin{array}{l}\text { の凡例： } \\
\text { ¿)=Not } \\
\text { are avai } \\
\text { らで不整列 } \\
\text { まど小さし }\end{array}$ & $\begin{array}{l}\text { =Existence 有 } \\
\text { measured 未計測 } \\
\text { able. 一部崩落部 } \\
\text { リに積まれている } \\
\text { 石を使用 }\end{array}$ & $\begin{array}{l}\text { 小 } x=\text { Not exist } \\
\text { いら壁体断面の観 }\end{array}$ & $\begin{array}{l}\text { nce 無し、 } \\
\text { 冬りり、外:Visual obse }\end{array}$ & tion only. 外観観察のみ & & & \\
\hline$※ 3$ & $\begin{array}{l}\text { Witho } \\
\text { Muc } \\
x: N\end{array}$ & ut: No ea & $\begin{array}{l}\text { th was } \\
\text { use mu }\end{array}$ & $\begin{array}{l}\text { used to pile up t } \\
\text { ch earth between } \\
\text { is earth to pile }\end{array}$ & the st & $\begin{array}{l}\text { es. 石を積むt } \\
\text { es. 石と石の } \\
\text { ones on. 石を }\end{array}$ & に土土 & $\begin{array}{l}\text { 丕使用 } / \mathrm{LittI} \\
\text { の土を使用 / } / \mathrm{Li} \\
\text { の土があるかど }\end{array}$ & $\begin{array}{l}\text { 少:A small am } \\
\text { tle } \rightarrow \text { Much 少 } \rightarrow \\
\text { か不明 }\end{array}$ & $\begin{array}{l}\text { of earth is used } \\
\text { There is more ear }\end{array}$ & $\begin{array}{l}\text { the stones. 石と石 } \\
\text { e top. 上部に行くほ }\end{array}$ & $\begin{array}{l}\text { に少量 } \\
\text { を多く }\end{array}$ & 上を使用 & \\
\hline
\end{tabular}


この場合は天井が載っている。(9)(10は京呂組になっており (9)は敷梁 が存在する。また、出桁造りの (6)(7)(8)は、出林造りの側は出梁を受 けるために桁が下になる京呂組で、反対部分は折置組である。出桁 造りの場合は室内だけでなく、妻壁も同じ取り合いになる。

天井をもつ灰屋は 7 件 (切妻 No. 8、10、12、19、茅莫 No. 15、28、 29)で、室内の半分程度を覆うロフトのような天井は 4 件 (No. 17、 18、20、30)であった。天井ではなく梁に荷物を載せている場合は 14 件であった。No. 18 と 20 は小屋梁とは別の材で支えるためにロフト 部分は(5)の方法をとっている。天井は、梁の上に板材や竹を筫の子 のように敷き詰めており、No. 17、28 ではその上に土を載せて土天 井（どてんじょう）としていた。

出析造りの 4 件はすべて、Photo 5 (a)のように、妻面の中心に対 して棟木の芯が出桁側 (写真左側)に寄っており、桁を出すことで屋 根勾配が左右で異なることを防ぐ工夫がなされている。出桁造は軒 下空間を拡大し、戸がない入口からの雨水浸入防止や、作業スペー スの確保等が意図されていたと考えられる。

また、(2)はNo. 2、3、4 で迴神町、(4)の No. 28、29、30 は世羅郡に、 (6) (7) (8)の出桁造りは No.1 を除き上田町に存在し、地域による偏り がみられた。

\section{5 開口}

Photo 5(b)のように、入口とは別に壁面上部にモノの出し入れを するような大きい開口 (半間以上)のあるものが 7 件あった。小屋梁

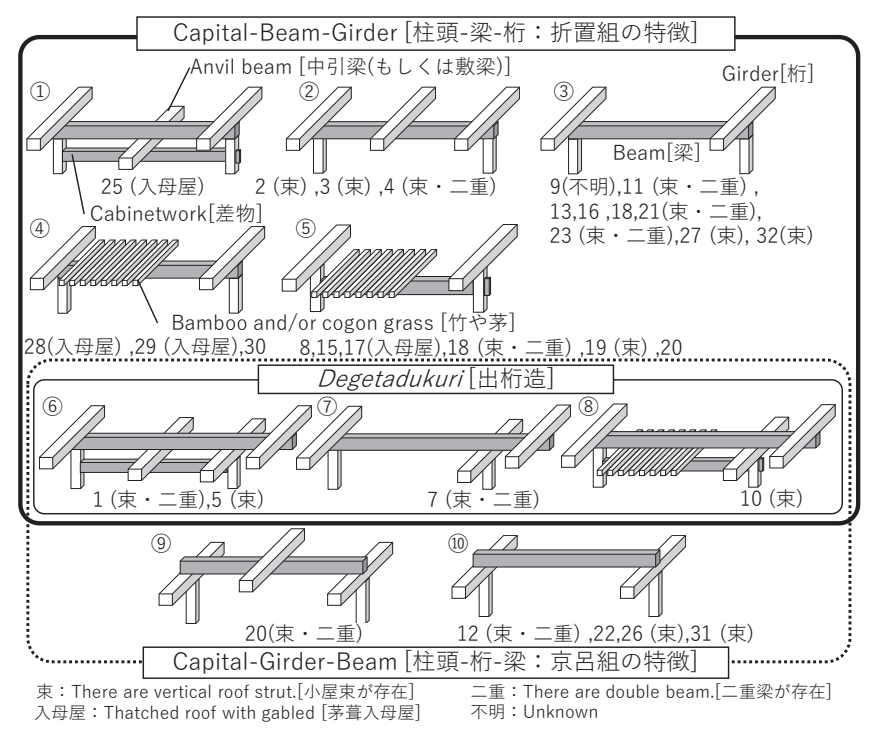

Fig. 11 Types of beams and girders in the room

(With the exception of "Degetadukuri", all beams are below and girders are above on the gable side)

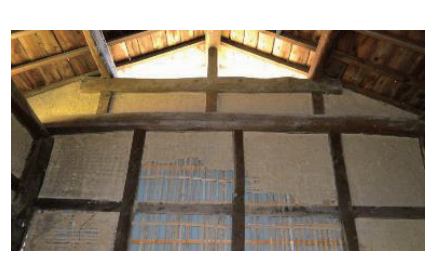

(a) Smoke vent opening [煙抜き用の開口]

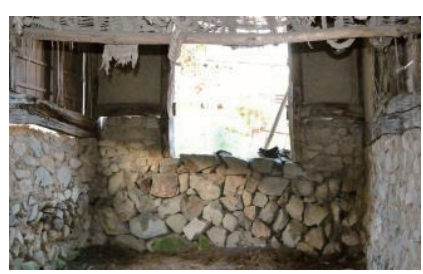

(b) Opening for carry in [出し入れ可能な開口]
Photo 5 Type of openings (No. 18)
上部の妻部分は、Photo 5(a)のように屋根付近の一部に開口が設け てあるものがあった。灰屋内部で灰を作製していた場合があること から、煙の排出のために妻部分に開口を設けていた可能性がある。

\section{5. 考察}

\section{1 用途と空間構成}

(1) 平面構成

平面構成の分類をFig. 12 に示す。まず平入と妻入に大別し、下屋 (柱だけの場合と壁がある場合) が付属する場合および高低差を利用 している場合とで分類を行った。調查した地域の灰屋 32 件のうち、 平入が 25 件、妻入り 7 件であった。下屋ありは平入妻入あわせて 15 件で、壁を有する下屋をもつのはそのうち 10 件であった。高低 差を利用するために傾斜地を掘りこんで建てている灰屋 (Fig. 12 灰 色部分に囲まれている灰屋) は 6 件で、そのうち 2 階建ては 2 件で あった。

平入は規模が様々だが入口は基本的に平側の中心である。妻入は 高低差を利用した灰屋以外は、 $20 \mathrm{~m}^{2}$ 以下かつ梁間が $2645 \sim 3508 \mathrm{~mm}$ の小規模な灰屋が多く、片側の妻面全体が出入口となっている。

\section{（2）納屋としての機能とつくり}

下屋は土・石積み壁に囲まれた中心部と同様の材と組み方のもの もあるが、一方で中心部では使われていない釘やかすがいで留める 場合や差し物に梁を載せているだけの場合など、用途が灰の作製か ら物置に変化していったことで増設された可能性が考えられるもの も確認された。

また、Fig. 11(4)(5)(8ような天井・ロフトのある場合、No. 28 以 外はすべて収納に利用されている。入母屋茅莫の場合は屋根勾配が 急なため、比較的屋根裏空間を確保しやすいが、切妻では難しい。 そこで Fig. 11(5)(8)ように梁を柱への差し込みとして高さを調節 し、小屋組の高さに影響を受けないようにしたうえで、天井裏の空 間を確保していた可能性が考えられる。

\section{（3）高低差を生かした用途}

高低差を生かす 6 件の灰屋うち 2 階建てを除く 4 件の灰屋は、高 い方の地面と同じレベルに大きい開口 (Photo 5 (b)) があり、葈・枝 およびゴミなどの搬入に利用することが確認された。文献 ${ }^{21}$ からも 同様に搬入に関する記載がある。2 階建ての場合は、Fig. 8 (b) に示 すような建物の壁の一部として利用し、高い地面を 2 階への出入り に利用することが確認できた。2 階部分は物置として使われていた。

\section{2 灰屋の材料・構法および工法}

\section{(1) 柱と差し物の接合方法}

湾曲した材同士 (特に柱と差し物)の接合には、Photo 6 に示すよ うに鼻栓および込栓が用いられていた。入口まわりは込栓による接 合が多いが、建物四隅の柱と差し物の接合は鼻栓が多い。また、差 し物のホゾに対して柱のホゾ穴が、高さ方向に大きく開けられ、鼻 栓又は込栓を用いたうえで隙間に楔を打ち込んでいる。湾曲材同士 を繋ぐうえで、材の上下の誤差を吸収するためにホゾ穴を大きくと り、貫通させたのち栓で固定し、楔でホゾ穴の隙間を埋める方法だ ったと考えられる。

また、鼻栓および込栓の用い方として、1 本の差し物を留めるの に鼻栓および込栓を両方用いる場合 (No. 1、4)、建物内で 1 つの柱は 鼻栓で留め、別の柱は込栓で留めるなど柱で留め方が異なる場合 
(No.25、17)、また、同じ柱に桁行方向の差し物は鼻栓 1 本、梁間方 向の差し物は鼻栓 2 本といったように梁間方向と桁行方向で鼻栓の 数が異なる場合 (No. 23、24、26、30、22) が確認できた。

(2) 壁高さ厚さ比

Fig. 13 に厚さ $(t)$ と高さ $(h)$ の関係を示す。地震地帯における石積 みや版築、日干しレンガなどによる伝統的な建造物を対象とした、 国際的な設計ガイドライン ${ }^{30)}$ では、安全の目安として壁の高さ厚さ 比 $(h / t) 8$ 以下を推奨している。本研究の灰屋は軸組構造で、この指 標が適当とは限らないが、壁上部の厚さ寸法を用いて $h / t$ を求める と、一部の灰屋で 8 を超えていたが、下部寸法を用いればすべての

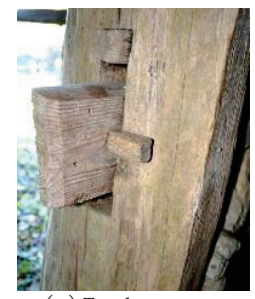

(a) Tusk tenon joint and cotter 鼻栓と楔の併用 (No. 29)

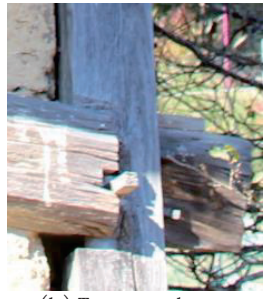

(b) Two tusk tenon joint and pinned joint 鼻栓 2 本と込栓の 併用 (No. 1) (c) Two tusk tenon joint (ridge direction) and one (beam direction) 桁行が鼻栓 2 本て 梁間は 1 本(No. 23)

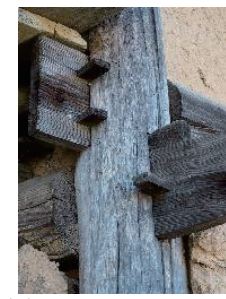

Photo 6 Column - Sashimono joint
灰屋において 8 以下におさまっており、その多くが 4 程度であるこ とがわかった。

（3）柱および差し物の塗込め

柱は、室内側では差し物の高さまで土で塗り込められており、差 し物より上部および室外 (No. 11 を除く) は表しになっていた。柱の 室内側の塗込めは、内部で火をつけて灰をつくるときの延焼防止が 目的であり、室内上部がむき出しになっていたのは灰の作製方法と して、枝・草を積み上げ、土で覆ったことで炎があまり出なかった

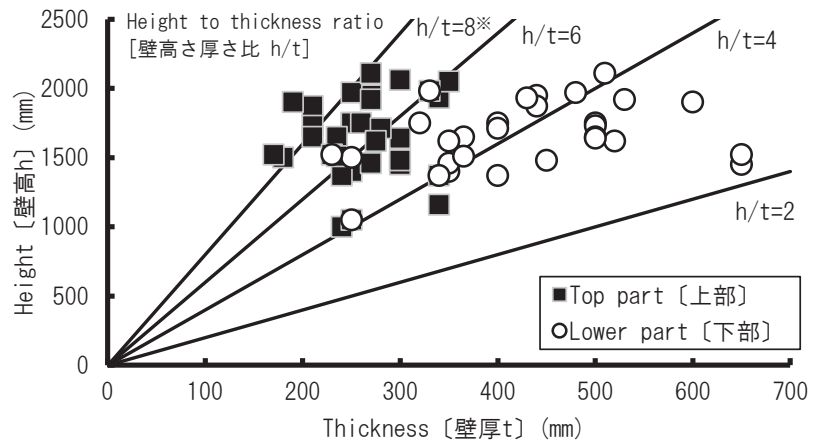

※s for the indication of the security in the earthquake-prone zone, values less than 8 are recommended by literatures ${ }^{30)}$ [文献30)では地震多発地帯における安全の目安として8以下を推奨]

Fig. 13 Relationship between thickness and height of earth and stone masonry wall

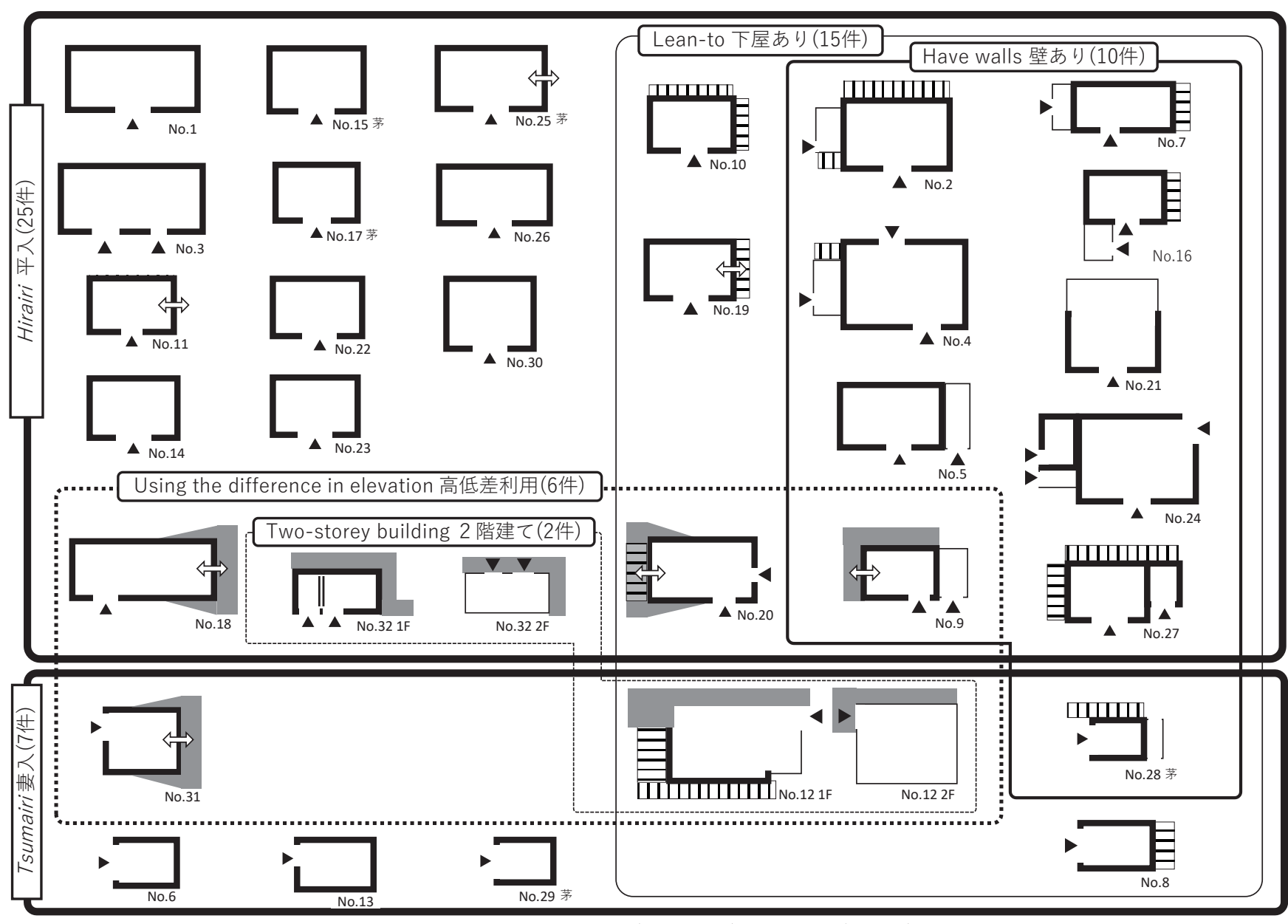

：Earth-stone masonry walls 土・石積み壁 $=$ : Earth-stone masonry walls (to waist-high) 土・石積み壁（腰高まで）－－Daub・Tin-plate 小舞土壁・トタン貼り壁

WI : Lean-to(pillar only) 下屋（柱のみ） $\square$ : Slope(the difference in elevation) 斜面（高低差） $\Longleftrightarrow$ : In-and-out opening 出し入れ用開口 茅: Thatch 入母屋茅驀

Fig. 12 Classification of the plan configuration 
ことと、木と土の積み上げた高さが差し物の高さと同じ(この高さま でしか積まなかった)ため、と考えられる。この高さは、灰の作製に 必要な高さや、土・石積み壁を足場無しで施工可能な限界であるお よそ $2000 \mathrm{~mm}$ 前後という高さと関係していると考えられる。なお、差 し物は、その多くが室内側でも表しになっていたが、5 件において 土で塗り込められている様子が確認できた。

\section{3 灰屋の構成と役割の変化}

文献調查および聞取り調查の結果から、灰屋は当初、田畑の肥料 としての灰を焼く場所であったが、化学肥料の出現によってその役 割を終えて様々なものの置き場になって今に残っていることが分か った。「日本の民家」 ${ }^{18)}$ において、確認されている灰屋の中では、Fig. 3 (4)の芝土を載せた掘立柱の灰屋や(6)のようなタイプが、最も簡易な 形式の灰屋で、灰を作る量が少ない場合はこの程度でも十分であっ たと考えられる。

しかし、耕作面積の増加や面積当たりの収穫量増大を目指して、 Fig. 311のような大きな灰屋が現れたと考えらえる。また、地域によ っては 3.6 で述べたように、灰屋の大小や戸数が財力や百姓の能力 を示すという象徴的な役割も持つようになったと考えられる。

今回の調査で確認できた切妻と入母屋茅莫のタイプは Fig. 3(1) と 同じ形であり、100 年ほど前には既に成立していたことが分かる。 なかでも瓦草きで切妻のタイプが瓦の普及とともに広がり、現在の 標準的なものとして残ったと推測される。

\section{6. まとめ}

本研究では、国内の土・石積み壁を有する建築として、広島県三 次市・世羅周辺の灰屋を調查した。その結果以下のことが明らかに なった。

(1)この地域では、田畑にまく肥料として用いる灰を、灰屋と呼ば れる小屋の中で、木の枝や落ち葉を積んで土を被せて焼くこと で作製していた。化学肥料の普及とともに役割を終え、現在は ほとんど物置として使われている。

（2）内部で火を焚くことを考慮し、主屋から離れた敷地の隅や田畑 の中に建てられている。50 年以上前から建っているものが多く、 木造軸組構法による切妻瓦莫きで平入の平屋が最も基本的な形 式で、下屋のある場合や高低差を利用したもの、2 階建てのもの も存在が確認された。

特徴的なのは、湾曲材を用いた柱と差し物からなる軸組で、差 し物から下は土・石積み壁となっている。これらの湾曲材を接 合するために、鼻栓・込栓・楔を様々に用いていることが分かっ た。木材は近隣の山から採取してきており、特に柱には耐久性 がある栗材が好まれた。

（3）土・石積み壁は、近隣からとれる土と石を用いてつくられてい る。土・石積み壁の内部には垂直材が配されているものもあり、 土や石を積む際のガイドまたは柱梁構造と合わせて、土・石積 み壁には荷重を負担させない間柱のような役割が推定できる。 積み方は、石の大きさ・積み方ともにまばらである場合がほと んどだが、壁の上部ほど石が小さくなる積み方もあり、下部の 大きな石は基礎としての役割もうかがえる事例が確認された。 土・石積み壁の表面、特に屋外の壁表面には上塗りが施される 場合があった。

\section{謝辞}

調査地域住民の方々に貴重なお話を頂戴した。また、奈良女子大 学の藤田盟児教授に貴重な情報とご意見を頂いた。真鍋結美さん(当 時，奈良女子大学 3 回生）、河内駿君・MAGNONDE COMLAN GUY 君（当 時, 近畿大学 3 回生）には調査にご協力頂いた。ここに記し、感謝 の意を示します。

\section{参考文献}

1) Miyamoto, N.: Housing Architecture in Primitive and Ancient Japan, Chuokouronbijyutu Publisher, pp.110-111, 1996.7 (in Japanese) 宮本長二郎：日本原始古代の住居建築, 中央公論美術出版, pp.110-111, 1996.7

2) Takada, K. et al.: Reconstruction of a Jomon Period Earthen Roof House (1), Cultural Assets Journal, pp.55-59、1998.6 (in Japanese) 高田和徳, 西山和宏, 浅川滋男 : 縄文時代の土屋根住居の復元(一), 月刊 文化財, pp.55-59, 1998.6

3) Aoki, T.: Ancient History of Civil Engineering Technology, Yoshikawakoubunkan, pp.63-69, 80-89, 112-141, 2017.10 (in Japanese)

青木敬：土木技術の古代史, 吉川弘文館， pp. 63-69， 80-89，112-141， 2017. 10

4) Hatanaka, K.: A Study of the Earth Wall how to Structure - Through an Inspection Experiment of the "Rammed earth" "Cob-wall", Kyoto Institute of Technology Doctoral Dissertation, 2016 (in Japanese) 畑中久美子 : 土壁構法の研究「版築」「団子積夕」「練り土積み」の検証 実験を通して, 京都工芸繊維大学博士論文，2016

5) Akiko, K. et al.: Research on regional characteristics of architecture no. 1 The storehouse of the mud in the Yamaguchi Prefecture Toyouracity are made into an Example, Research Reports of AIJ Chugoku Branch, Vol.28, pp.701-704, 2005.3 (in Japanese) 児玉亜希子, 内田文雄:建築の地域性に関する研究 その 1 山口県豊浦 町の土の蔵を事例として, 日本建築学会中国支部研究報告集, 第 28 巻, pp. 701-704, 2005. 3

6) Oba, S. et al. : The Old Farm Houses Supported with Stone Walls in Makino District of Nagasaki City - A Study on the Old Houses with Stone Walls or Stone Base Called "Dohyo-Motase" in Nagasaki Prefecture, Part1 Part5, Summaries of Technical Papers of Annual Meeting, Architectural Institute of Japan, F-2, pp.551-560, 2011.7 (in Japanese)

大場修ら:長崎県の練塀と「どひょもたせ」を持つ民家について その 1 〜その 5, 日本建築学会大会学術講演梗概集, F-2 分冊, pp. 551-560, 2011. 7

7) Nakamura, W. et al.: Study on Cob Construction Method in Japan Report 1 The Measurement of the Warehouses and the Walls in Nara Prefecture, AIJ Journal of Technology and Design, Vol.25, No.60, pp.881-886, 2019.6 (in Japanese)

中村航, 山田宮土理, 村本真, 畑中久美子 : 奈良県山の辺の道周辺の小 屋・塀に関する実測調査一日本における土積み構法に関する研究 その 1 , 日本建築学会技術報告集，第 25 巻，第 60 号, pp. 881-886, 2019. 6

8) Nakamura W. et al.: Mud and Stone Masonry Construction Method in Japan Report 5 Interviews of Warehouses in Oita Prefecture, Summaries of Technical Papers of Annual Meeting, Architectural Institute of Japan, Architectural Planning and Design, pp.1267-1268, 2020.7 (in Japanese)

中村航，中村美貴，山田宮土理，畑中久美子，森下啓太朗：日本におけ る土と石を用いた組積構法に関する研究 その 5 大分県国東半島の小屋 に関する聞取り調査, 日本建築学会大会学術講演梗概集, 建築計画, pp. $1267-1268,2020.7$

9) Nakamura M. et al.: Mud and Stone Masonry Construction Method in Japan Report 6 The Measurement of Warehouses in Oita Prefecture, Summaries of Technical Papers of Annual Meeting, Architectural Institute of Japan, Architectural Planning and Design, pp.1269-1270, 2020.7 (in Japanese)

中村美貴, 中村航, 山田宮土理, 畑中久美子, 森下啓太朗 : 日本におけ 
る土と石を用いた組積構法に関する研究 その 6 大分県国東半島の小屋 に関する実測調査, 日本建築学会大会学術講演梗概集, 建築計画, pp. 1269-1270, 2020.7

10) Morishita K. et al.: Mud and Stone Masonry Construction Method in Japan Report 7 The Measurement of Masonry Walls of Warehouses in Oita Prefecture, Summaries of Technical Papers of Annual Meeting, Architectural Institute of Japan, Architectural Planning and Design, pp.1271-1272, 2020.7 (in Japanese)

森下啓太朗, 山田宮土理, 中村航, 中村美貴, 畑中久美子 : 日本におけ る土と石を用いた組積構法に関する研究 その 7 大分県国東半島の小屋 の壁体部に関する実測調査, 日本建築学会大会学術講演梗概集, 建築計 画, pp. 1271-1272, 2020.7

11) Oono S. et al.: Hanya in Shiga prefecture - A case study of a farming community on the right side of the Aichi river, Summaries of Technical Papers of Annual Meeting, Architectural Institute of Japan, Rural Planning, pp.205-206, 2013.7 (in Japanese)

大野沙織, 濱崎一志: 滋賀県における灰小屋に関する研究一愛知川右岸 の農村集落を事例として一, 日本建築学会大会学術講演梗概集, 農村計 画, pp. 205-206, 2013.7

12) Takagi Yosimi: What you can see from the Hainaya (Toyama Folk Society: Toyama Folk 70) (in Japanese) , pp.1-7, 2008 (in Japanese) 高木好美: 灰納屋からみえてくるもの（富山民俗の会編：とやま民俗 70), pp. 1-7, 2008

13) Yamada M. et al.: Mud and Stone Masonry Construction Method in Japan Report 1 Interviews of Warehouses in Hiroshima Prefecture, Summaries of Technical Papers of Annual Meeting, Architectural Institute of Japan, Architectural Planning and Design, pp.943-944, 2019.7 (in Japanese)

山田宮土理, 中村美貴, 中村航 : 日本における土と石を用いた組積構法 に関する研究 その 1 広島県三次・世羅周辺の小屋に関する聞取り調 査, 日本建築学会大会学術講演梗概集，建築計画，pp. 943-944，2019.7

14) Nakamura M. et al.: Mud and Stone Masonry Construction Method in Japan Report 2 The Measurement of Warehouses in Hiroshima Prefecture, Summaries of Technical Papers of Annual Meeting, Architectural Institute of Japan, Architectural Planning and Design, pp.945-946, 2019.7 (in Japanese)

中村美貴, 中村航, 山田宮土理 : 日本における土と石を用いた組積構法 に関する研究 その 2 広島県三次・世羅周辺の小屋に関する実測調査, 日本建築学会大会学術講演梗概集, 建築計画, pp. 945-946, 2019.7

15) Imanaka M. et al.: Mud and Stone Masonry Construction Method in Japan Report3 The Measurement of Masonry Walls of Warehouses in Hiroshima Prefecture, Summaries of Technical Papers of Annual Meeting, Architectural Institute of Japan, Architectural Planning and Design, pp.947-948, 2019.7 (in Japanese)

今中美琴, 中村航, 山田宮土理, 中村美貴 : 日本における土と石を用い た組積構法に関する研究 その 3 広島県三次・世羅周辺の小屋の壁体部 実測結果, 日本建築学会大会学術講演梗概集, 建築計画, pp. 947-948, 2019. 7

16) Matsumoto Rinichi : Folklore of Fire in the Chugoku and Shikoku regions, Meigen publishing company, pp.103-106, 1985 (in Japanese) 松本麟一：中国・四国地方の火の民俗, 明玄書房, pp. 103-106, 1985

17) Oosima, Matsuzaki Kenzou, Miyamoto Kesao : Collection of Reports of the Japanese Folk Survey - Folklore of the Chugoku Region in Hiroshima Prefecture, San-ichi publishing company, pp.63-67, 1997 (in Japanese)

大島暁雄, 松崎憲三, 宮本架乷男: 日本民俗調査報告書集成 中国の民 俗広島県編, 三一書房, pp. 63-67, 1997

18) Kon Wajiro : Minka in Japan, Oka publishing company, pp.199-200, 1922 (in Japanese)

今和次郎: 日本の民家, 岡書院, pp. 199-200, 1922

19) Tsurufuji Shikatada : Minka in Chugoku region, Mingen publishing company, pp.317-318, 1966 (in Japanese) 鶴藤鹿忠: 中国地方の民家，明玄書房，pp. 317-318, 1966

20) Hiroshima Prefecture: History of Hiroshima Prefecture Folkloric edition, p.141, pp.939-946, 1978 (in Japanese)

広島県:広島県史 民俗編, p. 141, pp. 939-946, 1978
21) Hiroshima folklore association: Housing and Clothing, Food and Hiroshima Prefecture Ethnographic Data Vol.3, Mikoku publishing company, p.80, 1970 (in Japanese)

ひろしま・みんぞくの会:すまいと衣食一広島県民族資料 第 3 集，三国 書院, p. 80, 1970

22) Jouge town historiography editing committee, Jouge town Board of Education: History of Jouge town Folkloric edition, pp.233-234, 1991 (in Japanese)

上下町史編纂委員会，上下町市教育委員会：上下町史〈民俗編〉, pp. 233234, 1991

23) Shobara City Taka Community Center: Home of the Heart - Life in the Showa Period Farming Village Tied to the People of the Taka Area, Taka Area Community Development Promotion Council, p.207, 2005 (in Japanese)

庄原市高公民館：心のふる里一高地域の人たちのつづる昭和の農村の暮 らし-，高地区明るい地域づくり推進協議会，p. 207，2005

24) Historiography editing committee of Kimita village : History of Kimita Village」, Kimita Village, p.1017、1991 (in Japanese) 君田村史編さん委員会:君田村史，君田村，p. 1017， 1991

25) Aoga Hometown Exploration Association, Aoga Local Government Association: Ash hut and Wood Hut in Aoga Town, Aoga Hometown Exploration Association and Aoga Local Government Association, pp.1-7、2009 (in Japanese)

青河ふるさと探訪の会，青河自治振興会: 青河町の灰屋と木小屋，青河 町ふるさと探訪の会・青河自治振興会, pp. 1-7, 2009

26) Kouwa town Historiography editing committee: History of Kouwa Town, Kouwa town, p.737, 2000 (in Japanese) 口和町誌編纂委員会:口和町誌, 口和町, p. 737, 2000

27) Takadagun Historiography editing committee: History of Takadagunn Folkloric edition, pp.123-127, 1979 (in Japanese) 高田郡史編纂委員会: 高田郡史 民俗編，高田郡町村会，pp. 123-127， 1979

28) Shimomukaiwakuwakumachidukuri community - Ban East Shimomukai town community : Romantic Road, p.80, 2015 (in Japanese)

下向わくわくまちづくりの会・伴東下向町内会：ロマン街道・下向, p. 80, 2015

29) Moritsuka, N., Matsuoka, K.: Past and present studies on the agronomic effects of soil heating, Japanese society of soil science and plant nutrition, No.79, Vol.5, pp.505-510, 2008.10 (in Japanese) 森塚直樹, 松岡かおり : 焼土効果研究の過去と現在, 日本土壌肥料学雑 誌, No. 79, Vol.5, pp. 505-510, 2008. 10

30) Anand S. et al.: GUIDELINES FOR EARTHQUAKE RESISTANT NON-ENGINEERED CONSTRUCTION, UNESCO, pp.129-130, 2014.5

注

注1） 青木 ${ }^{32}$ は寺の基壇や古墳の築造技術として版築や土囊・土塊積み技術 が伝わったとしている。また栗原柳庵 $(1794 〜 1870)$ は『柳庵随筆（三 の巻 柱なしの土蔵）』の中で、長さ三尺、幅一尺、高さ二尺の箱に土 を詰めて突き固め、日に干して、石垣のようにかさねて土蔵をつくる 方法が長州萩某造営書にある、と記載している。

注2）焼土の効果は、広義には加熱による土壤養分の可給化および有効化と 土壌病原菌や雑草の種子の死滅が含まれる。日本で行う焼土は田畑の 隅で土と葍や芝草・枝を積んで然や寸ことが共通しており、植物灰の 添加という意味も含んでいる 29)。広島の灰屋で作製する灰も、これら の焼土と類似の方法で作製しており、役割も同様であると考えられる。

注3）中国地方の方言で乞食のこと。

注4） 1910 年代にアンモニア合成法が開発され、日本でも 1920 年代から窒 素肥料である硫酸アンモニウムの消費量が増加した。その他の化学肥 料の生産量も増加し、1940 年代には焼土肥料の習慣は途絶えていった。 戦争中は化学肥料より爆薬や燃料の生産を優先したため、一時的に化 学肥料は激減したが、戦後はまた増加していった ${ }^{29)}$ 。戦時中の化学肥 料の減った時期は、灰屋による焼土も多く利用されていた ${ }^{17)}$ 。 


\title{
CONSTRUCTION METHOD OF STACKING EARTH AND STONE IN JAPAN (PART 1) : “HANYA” WITH EARTH AND STONE MASONRY WALL IN THE VICINITY OF MIYOSHI AND SERA, HIROSHIMA PREFECTURE
}

\author{
Wataru NAKAMURA *1, Midori YAMADA *2 and Miki NAKAMURA*3 \\ ${ }^{-1}$ Assist. Prof., Dept. of Architecture, Nara Women's Univ., Dr.Eng. \\ ${ }^{2}$ Assoc. Prof., Dept. of Architecture, Waseda Univ., Dr.Eng. \\ ${ }^{3}$ Nara Women's Univ., B. Human Life and Environment
}

In Hiroshima Prefecture, there are warehouse called "Hanya" which have earth and stone masonry walls and are used for the production and storage of ash. In this study, we investigated the constitution and use of ash houses to clarify the architectural characteristics of Hanya. Sixty-five shacks were found mainly in Miyoshi City, Hiroshima Prefecture, and most of them were found along the Mihara River in Miwaka Town and Aribara Town, and in Ueda Town.

We conducted a survey, interview, and literature research. As a result, we found the following.

(1) The ashes are created by piling up tree branches and fallen leaves, covering them with earth and burning them. It was built in a corner of the site away from the main house and in the fields, with the intention of building a fire inside. Many of them have been built more than 50 year ago. The role of the ash house has changed from burning and storage of ashes to almost a storage room.

(2) The most basic form was a single-story house with a gable-tile roof using the wooden-frame construction method. It has been confirmed that there are some cases of sheds and two-story structures based on this form. In all the warehouse that used the difference in elevation, the higher part of the ground was used as the entry point for bringing in grass, branches, etc. and for people to enter and exit.

The most distinctive feature is the wood framework, which consists of column tilted inward and a horizontal member "Sashimono", and a wall under Sashimono is constructed earth and stone masonry.

(3) Earth and masonry walls are constructed using materials from the neighborhood. There is vertical timber inside the wall to support the load from upper the wall or to be used as a guide during stacking. The height of the wall matches the height for burning ashes. In other words, it matches the height at which a human being can stack things without scaffold. There are two ways to stack the earth and stones, (1) the stones are sparse in both size and stacking, and (2) the stones are smaller at the top of the wall. Earth-stone masonry wall surfaces, especially outdoor wall surfaces, may be coated with a top coat. 